\title{
Faunal changes and geographic crypticism indicate the occurrence of a biogeographic transition zone along the southern East Pacific Rise
}

\author{
Matabos M. ${ }^{1,2,{ }^{*}}$, Plouviez S. ${ }^{2,3}$, Hourdez S. ${ }^{2,3}$, Desbruyères D. ${ }^{4}$, Legendre P. ${ }^{5}$, Warén A. ${ }^{6}$, Jollivet D. ${ }^{2,3}$ \\ and Thiébaut $\mathrm{E}^{2,3}$ \\ ${ }^{1}$ Muséum National d'Histoire Naturelle, Département Milieux et Peuplements Aquatiques, UMR \\ BOREA 7208 (MNHN, UPMC, CNRS), CP 53, 61 rue Buffon, F-75231 Paris cedex 05, France \\ ${ }^{2}$ CNRS, UMR 7144, BP 74, F-29682 Roscoff cedex, France \\ ${ }^{3}$ Université Pierre et Marie Curie, Station Biologique de Roscoff, UMR 7144, Laboratoire Adaptation \\ et Diversité en Milieu Marin, F-29680 Roscoff cedex, France \\ ${ }^{4}$ Ifremer, Département Etude des Ecosystèmes Profonds, BP70, F-29280 Plouzané, France \\ ${ }^{5}$ Département de Sciences Biologiques, Université de Montréal, C.P. 6128, succursale Centre-ville, \\ Montréal, Québec, H3C 3J7, Canada \\ ${ }^{6}$ Swedish Museum of Natural History, Box 5007, SE-10405, Stockholm, Sweden
}

\begin{abstract}
*: Corresponding author : Matabos M., Present address: School of Earth and Ocean Sciences, University of Victoria, PO Box 3065, STN CSC, British Columbia, Victoria, V8W 3V6, Canada, email address : mmatabos@uvic.ca
\end{abstract}

\begin{abstract}
:
Aim Deep-sea hydrothermal vents have now been reported along all active mid-ocean ridges and back-arc basins, but the boundaries of biogeographic entities remain questionable owing to methodological issues. Here we examine biogeographic patterns of the vent fauna along the East Pacific Rise (EPR) and determine the relative roles of regional and local factors on the distribution of biodiversity associated with mussel beds along a poorly explored zone, the southern EPR (SEPR).
\end{abstract}

\section{Location East Pacific Rise.}

Methods A species list of macrobenthic invertebrates along the EPR was compiled from the literature and supplemented with data recovered during the French research cruise BIOSPEEDO carried out in 2004 along the SEPR. Biogeographic patterns were assessed by combining the identification of morphological species with a molecular barcoding approach. A multivariate regression tree (MRT) analysis was performed to identify any geographic breaks, and an empirical distribution of species richness was compared with predictions provided by a mid-domain effect model. Macrofaunal community structure associated with mussel beds along the SEPR was analysed in relation to environmental factors using cluster and canonical redundancy analyses.

Results Sequencing of the cytochrome $c$ oxidase subunit I gene revealed the occurrence of several cryptic species complexes along the EPR, with the equator separating the southern and northern clades. Furthermore, during the BIOSPEEDO cruise at least 10 still unnamed species were collected 
between $7^{\circ} 25^{\prime} \mathrm{S}$ and $21^{\circ} 33^{\prime} \mathrm{S}$. The shift in community structure identified by MRT analysis was located south of $17^{\circ} 34^{\prime} \mathrm{S}$ or south of $13^{\circ} 59^{\prime} \mathrm{S}$, depending on the data used, suggesting that the southern part of the SEPR $\left(17^{\circ} 25^{\prime}-21^{\circ} 33^{\prime} \mathrm{S}\right)$ constitutes a biogeographic transition zone in the vent fauna along the EPR. At a regional scale, latitude combined with the type of venting was significantly correlated with the community structure associated with mussel beds.

Main conclusions Together, the molecular data, in situ observations, and the distribution of species suggest that the high diversity of vent fauna species presently observed between $17^{\circ} 25^{\prime} \mathrm{S}$ and $21^{\circ} 33^{\prime} \mathrm{S}$ is probably a result of the overlap of several distinct biogeographic provinces. We argue that this area thus constitutes a biogeographic vent fauna transition zone along the EPR.

Keywords: Biogeographic patterns; community structure; East Pacific Rise; hydrothermal vents; marine biodiversity; molecular systematics; mussel beds; species richness 


\section{Introduction}

The discovery of dense communities of endemic species associated with hydrothermal vents on the Galapagos Rift in 1977 offered a new perception of deep-sea benthic fauna, far different from what was commonly accepted about the vast and unproductive abyssal plain (Lonsdale, 1977). Hydrothermal vents represent discontinuously distributed oases along oceanic ridges and at back-arc basins, volcanic arcs, and active seamounts. They are characterized by an ephemeral vent-fauna lifespan related to tectonic events and/or volcanic activity. The associated marine communities harbour high densities of macrobenthic fauna and have low species richness and low diversity resulting from the overwhelming numerical dominance of a few species. Organisms are clustered around vents, where they thrive on microbial chemoautotrophic primary production (Van Dover, 2000). These oases are characterized by variable numbers of rare species that are heterogeneously distributed in time and space depending on the vent conditions and faunal succession occurring during the early colonization of new vent emissions (Jollivet, 1996; Shank et al. 1998). In the Pacific, the vent fauna has adapted to the great instability of the habitat where strong variations in the geological setting (in relation to magmatic and/or tectonic activity) and the physical-chemical conditions (related to the temporal dynamics of the fluid discharge) naturally occur on a broad range of spatial (centimetres to thousands of kilometres) and temporal (seconds to years) scales (Juniper \& Tunnicliffe, 1997; Sarrazin et al., 1997).

Endemism at the specific and generic levels has raised questions about vent species origin and evolution: it was suggested that important groups of vent invertebrates originated and then independently evolved from the late Cretaceous and early Tertiary, i.e from around 65 Ma (Little \& Vrijenhoek, 2003). But the colonization pathways and the links between hydrothermal systems in the global ocean are still poorly understood despite the growing literature addressing biogeographic questions during the last decade (e.g. Tunnicliffe \& Fowler, 1996; Tunnicliffe et al., 1998; Van Dover et al., 2002; Tyler et al., 2003; Desbruyères et al. 2006a; Bachraty et al., 2009). The present distribution of vent fauna mainly reflects historical events (i.e. plate tectonics) and species' abilities to colonize distant territories (i.e. dispersion and migration) (review in Tunnicliffe et al., 1998). While dispersal and migration are major processes linking neighbouring vent communities (Tunnicliffe \& Fowler, 1996), the distance between neighbouring vents and habitat availability depends on the geodynamic nature of the ridge (i.e. volcanism or tectonism).

Based on faunal composition, the global ocean ridge system, consisting of a nearly continuous approximately $60000 \mathrm{~km}$ volcanic chain, and back-arc spreading centres, are assumed to harbour five main biogeographic provinces, named for the hydrothermal vent fields explored to date: the Northeast Pacific, the East Pacific Rise (EPR), the West Pacific back arc basins, the Mid-Atlantic Ridge (MAR), and the Southwest Pacific and Indian Ocean. However, depending on the authors, five to seven biogeographic entities can be erected based on the literature, often differing in delimitations within an ocean (Tunnicliffe, 1991; Tunnicliffe et al., 1998; Van Dover et al., 2002; Tyler et al., 2003; Bachraty et al., 2009). As an example, while the Mid-Atlantic ridge is considered to form a single biogeographic province by most authors (e.g. Tunnicliffe et al., 1998; Tyler et al., 2003; Desbruyères et al., 2006a; Bachraty et al., 2009), Van Dover et al. (2002) defined the Azores plateau and the MAR as two distinct provinces. Similarly, depending on the authors, the West Pacific backarc basins form one or two (north vs. south) biogeographic provinces (e.g. Tyler et al., 2003; Bachraty et al., 2009). The differences among authors depend on the methodology and criteria used to define the biogeographic units, as no clear comprehensive classification exists for the deep sea in comparison with the coastal ocean (Spalding et al., 2007). On the other hand, the global database of species inventory is far from being complete and is still growing with the exploration of new fields.

Since 1977, taxonomists have described 592 morphological species belonging to 320 genera from vents, including 470 species and 251 genera of macrobenthic invertebrates (Desbruyères et al., 2006b; Bachraty et al., 2009). However, all known vent sites have not 
undergone the same sampling effort, and biodiversity is probably underestimated in poorly explored zones. Moreover, previous biogeographic analyses did not account for the occurrence of sibling species, which are widespread in the marine environment (Knowlton, 1993). In addition to the identification of morphospecies, molecular systematics is a powerful tool to help address biogeographic issues as it tells how species separate or expand in time and space (Vrijenhoek, 2009). Comparative phylogeography (i.e. the comparison of phylogeographic patterns among multiple co-distributed taxa) has strong parallel with historical biogeography and can help in identifying vicariant events unveiled by taxonomy (Arbogast \& Kenagy, 2001). To date, cryptic species have been reported from hydrothermal vents for many taxa separated by physical geological discontinuities that offset the ridge system (e.g. Won et al., 2003; Hurtado et al., 2004; Young et al., 2008). Along the EPR, the presence of cryptic species complexes was highlighted for lepetodrilid species (Johnson et al., 2008; Matabos et al., 2008a). A strong genetic divergence between a northern and a southern lineage was also observed from a set of taxonomic groups suggesting the occurrence of permeable genetic boundaries around the equator (e.g. Hurtado et al., 2002; Won et al., 2003; Hurtado et al., 2004; Matabos et al., 2008a). This hypothesis was recently supported by Plouviez et al. (2009) who demonstrated that the recent ridge history of the East Pacific Rise led to a vicariant event that induced genetic divergence across the equator about $1.3 \mathrm{Ma}$ for nearly all vent taxa.

The southern East Pacific Rise (SEPR), which is among the fastest spreading ridge centres in the world $\left(150 \mathrm{~mm}\right.$ year $\left.^{-1}\right)$, is characterized by a high instability in hydrothermal venting often associated with recent effusive volcanism (Auzende et al., 1994; Fouquet et al., 1994; Embley et al., 1998). While this portion of the EPR has been extensively studied from the geological, tectonic and geochemical points of view (Auzende et al., 1994; Fouquet et al., 1994; Fornari \& Embley, 1995; Fujioka et al., 1995; Embley et al., 1998), few papers have dealt with faunal composition across vent fields and these were based on few sampling units and study sites. The first analyses of faunal assemblages along the SEPR described fauna similar to the northern part of the EPR (Auzende et al., 1994; Geistdoerfer et al., 1995; Halanych et al., 1999). From quantitative sampling units, Van Dover $(2002,2003)$ proposed that the East Pacific Rise represents a single hydrothermal biogeographic province over at least 31 degrees of latitude, the differences relying solely on the relative abundances of the dominant species and the distribution of rare species. This author suggested that fields are not distant enough to prevent larval and/or adult dispersal in a stepping-stone manner (Van Dover, 2002). However, this author drew these conclusions after the analysis of a single particular habitat, the mussel beds. Recently, based on presence/absence of species for all hydrothermal vent fields in the global ocean, Desbruyères et al. (2006a) and then Bachraty et al. (2009) argued that the northern EPR (NEPR) and southern EPR (SEPR) are distinct provinces located on opposite sides of the equator. Despite a more or less continuous distribution of the vent fauna along the SEPR, the faunal assemblages consist of a succession of small patches dominated either by vestimentiferan tubeworms, bivalves, or stalked cirripeds, each of them resembling assemblages typical of $13^{\circ} \mathrm{N} / 9^{\circ} 50^{\prime} \mathrm{N} / \mathrm{EPR}$ for tubeworms, $21^{\circ} \mathrm{N} / \mathrm{EPR}$ for bivalves, or the West Pacific back-arc basins for cirripeds (Jollivet et al., 2005). These observations led to the hypothesis that this ridge portion may represent a transition zone between the NEPR fauna and those of the Atlantic or the West Pacific backarc basins, where species may have reached their range limits. In this context, the objective of the present study was two-fold:

To test the hypothesis that the SEPR could represent a transition zone between the NEPR and the other biogeographic regions found in the Pacific Antarctic Ridge and the Western Pacific. For this, the macrofaunal community structure was compared at two spatial scales: (i) along the whole East Pacific Rise from $21^{\circ} \mathrm{N}$ to $21^{\circ} 33^{\prime} \mathrm{S}$ using species lists, and then (ii) along the $7^{\circ} 25^{\prime} \mathrm{S}-21^{\circ} 33^{\prime} \mathrm{S} / \mathrm{SEPR}$ portion using a semi-quantitative dataset from 9 mussel beds at 6 hydrothermal vent fields in order to determine the relative roles of local and regional factors on mussel bed diversity.

To generalize the hypothesis of vicariance across the equator over nearly all vent habitats. This was assessed by a barcode analysis of the main gastropod species encountered along 
the EPR. Gastropod species are indeed an important component of the hydrothermal fauna diversity; they display various life history strategies and are found in all kinds of habitats (Jollivet, 1996; Mills et al., 2007).

\section{Materials and methods}

\section{Taxa, regions and data sources}

\section{The BIOSPEEDO cruise}

The oceanographic cruise BIOSPEEDO, conducted in the south-east Pacific in April/May 2004, aimed at understanding biodiversity patterns, and processes governing them, along the SEPR, a poorly explored but important ridge crossroads between biogeographic vent provinces (Jollivet et al., 2005). Six hydrothermal vent fields, governed by either effusive volcanism or tectonism, were thus intensively surveyed between $7^{\circ} 25^{\prime} \mathrm{S}$ and $21^{\circ} 33^{\prime} \mathrm{S}$ (Fig. 1). Areas driven by volcanic activity consist of a dome-shaped ridge crest where hydrothermal conduits resulting from seawater warming are short, shallow and unstable. Conversely, tectonic areas are characterized by a deep axial graben where hydrothermal fluxes are controlled by faults and are more stable through time (Fouquet et al., 1994). This fine-tuned latitudinal survey led to the collection of a large set of biological samples from a variety of habitats (i.e. diffuse venting zones, extinct chimneys, black smokers) and was performed in diverse faunal assemblages dominated either by bivalves, vestimentiferans tubeworms, alvinellids or Chorocaris shrimps swarms at $21^{\circ} 33^{\prime} \mathrm{S}$. In addition, an important sampling effort on mussel beds was conducted. A total of nine semi-quantitative sampling units of Bathymodiolus thermophilus beds were collected at six vent fields from both volcanic-dominated and tectonic-dominated zones between $7^{\circ} 25^{\prime} \mathrm{S}$ and $21^{\circ} 33^{\prime} \mathrm{S}$ (Table 1 ). Distances between neighbouring sites ranged from 3 to $891 \mathrm{~km}$, and between chimneys within a site (i.e. Grommit) from 30 to $147 \mathrm{~m}$. The study sites appeared to be at different successional stages (following Shank et al., 1998) such that three main types of habitats were sampled: extinct zones defined as areas with a lack of venting and almost devoid of fauna (moribund sites), diffusing venting areas (diffusion zones), and active black smokers (chimneys). For a brief description of all vent fields, see Jollivet et al. (2005).

\section{Benthic communities along the EPR (i.e. the global scale)}

A global species list of benthic macrofauna including only the main invertebrate taxa (i.e. gastropods, polychaetes and echinoderms) was assembled from the data compiled by Desbruyères et al. (2006b), and completed with the species list of the BIOSPEEDO cruise. Highly mobile epifauna (e.g. crustaceans) has intentionally been excluded, as it was not properly sampled during most hydrothermal cruises. A final list of species coming from chimney walls, vestimentiferan tubeworm clusters and mussel beds was thus compiled for nine hydrothermal vent fields: $21^{\circ} \mathrm{N}, 13^{\circ} \mathrm{N}, 11^{\circ} \mathrm{N}, 9^{\circ} 50^{\prime} \mathrm{N}, 7^{\circ} 25^{\prime} \mathrm{S}, 13^{\circ} 59^{\prime} \mathrm{S}, 17^{\circ} 25^{\prime} \mathrm{S}$, $18^{\circ} 36^{\prime} \mathrm{S}$ and $21^{\circ} 33^{\prime} \mathrm{S}$ (see Appendix S1 in Supporting Information). In order to detect biogeographic relationships more precisely given the usually non-quantitative nature of the sampling at hydrothermal vents, the data were analysed at the species presence-absence level (Desbruyères et al., 2006a; Bachraty et al., 2009).

Macrofaunal community structure associated with mussel beds along the SEPR (i.e. the regional scale) 
Details regarding the sampling units of Bathymodiolus thermophilus are presented in Table 1. All collections were performed using the hydraulic arm of the manned-submersible vehicle 'Nautile' (Ifremer). Mussels were washed on deck with filtered seawater and the associated fauna was collected onto a $1 \mathrm{~mm}$ mesh sieve. The animals were sorted onboard and the retained organisms were fixed in $4 \%$ neutral formalin or in absolute ethanol for subsequent molecular analyses. In the laboratory, all specimens were sorted, identified to the lowest possible taxonomic level, i.e. mainly to the species level, under a dissecting microscope and then transferred to $70^{\circ}$ ethanol. Data on echinoderm species correspond to those reported in Stöhr \& Segonzac (2006). Large and highly motile predators, including zoarcid fishes, squat lobsters (Munidopsis spp.) and bythograeid crabs, together with meiofauna and vagile epifauna (mainly amphipods and copepods) were not included in the analysis. Mussels $<10$ $\mathrm{mm}$, usually deemed to represent associated fauna at this life history stage rather than a structural component (Van Dover, 2002; Dreyer et al., 2005), were also not included in the analysis. The proportion of mussel specimens $<10 \mathrm{~mm}$, considered as juveniles, was regarded here as an indication of the mussel bed's condition (newly settled, mature, or senescent mussel beds): a newly settled mussel bed is expected to harbour lot of juveniles compared to senescent mussel beds.

Surface area (SA) of mussel shells was calculated by applying the relationship set between the mass of aluminium foil required to cover the outer surface of a mussel shell and mussel length (Bergquist et al., 2005). One hundred and six mussel shells, representative of the whole size range, were used to determine this relationship. The outer shells of each collection were wrapped in aluminium foil $\left(0.00363 \mathrm{~g} \mathrm{~cm}^{-2}\right)$, and the mass required to cover the entire shell was then converted to surface area (SA). Bias emerging from folding of the aluminium foil was considered equivalent for each mussel such that comparison between sampling units was valid. The relationship between SA (in $\mathrm{cm}^{2}$ ) and mussel shell length (L) was derived by plotting the surface area against the shell length to parameterize the following equation:

$$
S A=0.0137 L^{1.9671}
$$

This highly significant relationship $\left(R^{2}=0.996 ; P \leq 10^{-3}\right)$ was then applied to each mussel collection. Standardized abundances correspond to the number of individuals divided by the area sampled and are expressed as number of individuals $\mathrm{m}^{-2}$.

\section{Barcoding of hydrothermal gastropods}

The total genomic DNA was extracted using the CTAB (cetyltrimethyl ammonium bromide) procedure from ethanol-preserved specimens. Gastropods were removed from the shell, homogenized in $600 \mu \mathrm{L}$ of a $60^{\circ} \mathrm{C}$ preheated $2 \%$ CTAB buffer solution (containing $1.4 \mathrm{M}$ $\mathrm{NaCl}, 0.2 \%$ 2-mercaptoethanol, $20 \mathrm{mM}$ EDTA, $100 \mathrm{mM}$ Tris- $\mathrm{HCl} \mathrm{pH}$ 8, $0.1 \mathrm{mg} \mathrm{mL}$ proteinase $\mathrm{K}$ ) and digested for $2 \mathrm{~h}$ at $60^{\circ} \mathrm{C}$. Proteins, lipids and carbohydrates were removed using a single chloroform-isoamyl alcohol (24:1) precipitation. DNA was precipitated with 370 $\mu \mathrm{L}$ cold $100 \%$ isopropanol and stored at $-20^{\circ} \mathrm{C}$ for 1 to $2 \mathrm{~h}$. The tubes were finally centrifuged at $15000 \mathrm{~g}$ for $5 \mathrm{~min}$. DNA pellets were washed with $70-75 \%$ ethanol and resuspended in 20-60 $\mu \mathrm{L}$ of TE buffer (10 mM Tris- $\mathrm{HCl} ; 20 \mathrm{mM}$ EDTA pH 8) or sterile $\mathrm{H}_{2} \mathrm{O}$.

For each individual, partial sequences of the mitochondrial cytochrome c oxidase subunit I gene (COI) were amplified by conducting a "nested polymerase chain reaction (PCR)". DNA was pre-amplified with the universal primers M1 and M2 (Nelson \& Fisher, 2000) and used as a target ( $1 \mu \mathrm{l}$ of PCR-product) for a second amplification with the universal primers LCO1490 and HCO2198 described by Folmer et al. (1994). For both amplifications, the $50-\mu \mathrm{L}$ amplification mixture contained $3 \mu \mathrm{L}$ of template DNA, 1x PCR buffer, $2 \mathrm{mM} \mathrm{MgCl}_{2}, 0.4 \mu \mathrm{M}$ of each primer, $10 \mu \mathrm{M}$ of each dNTP, $2 U$ Taq DNA polymerase, and sterile $\mathrm{H}_{2} \mathrm{O}$ to final volume. PCRs were performed as follows: (a) a 3 min initial denaturation step at $94^{\circ} \mathrm{C}$, (b) 40 cycles of $45 \mathrm{~s}$ of denaturation at $94^{\circ} \mathrm{C}, 45 \mathrm{~s}$ of annealing at $50^{\circ} \mathrm{C}$ and $90 \mathrm{~s}$ of elongation at $72^{\circ} \mathrm{C}$ and, (c) a 7 min final elongation at $72^{\circ} \mathrm{C}$. 
The PCR products were purified and sequenced on ABI 3100 using BigDye ${ }^{\circledR}$ terminator chemistry (Applied Biosystems, Courtaboeuf, France) following the manufacturer's protocol. Sequences were proofread and aligned manually using BioEdit Sequence Alignment 7.0.1 (Hall, 1999).

Phylogenetic relationships between specimens were assessed for the wide-ranging species found in a large number in the sampling units: the lepetodrilids, i.e. Lepetodrilus elevatus, $L$. cristatus, L. ovalis, L. pustulosus, L. tevnianus, Gorgoleptis emarginatus and G. spiralis, the neomphalids Pachydermia laevis, the peltospirid Peltospira operculata and the neolepetopsid Eulepetopsis vitrea. Additional species, found in low proportions during the BIOSPEEDO cruise but well known from the East Pacific Rise were also added, i.e. Nodopelta subnoda and Rhynchopelta concentrica (peltospirids), and Clypeosectus delectus (lepetodrilids). Details about the specimens analysed are presented in Table 2. Aligned sequences were analysed by Bayesian inferences. First, the optimal substitution model for COI was selected using the hierarchical likelihood ratio test (hLRTs) implemented in Modeltest 3.07 (Posada \& Crandall, 1998). Then, Bayesian inferences were performed using the MrBayes 3.1.1 program (Ronquist \& Huelsenbeck, 2003) that uses a Markov chain Monte Carlo (MCMC) method for exploring the parameter space in a stepwise fashion. The analysis, involving 6 chains, was run for $10,000,000$ generations with a sampling frequency of 1,000 and a burn-in period of 10,000. The trees were unrooted.

Published mitochondrial COI sequences from Lepetodrilus elevatus [GenBank accession numbers EU306401-EU306402 and EU306407-El306408 described as L. aff. elevatus (Johnson et al., 2008)], L. pustulosus [GenBank accession numbers EU306457-EU306458 and EU306464-EU306465 for L. aff. pustulosus (Johnson et al., 2008)], L. cristatus [GenBank accession numbers EU306425-EU306426], L. ovalis [GenBank accession numbers EU306478-EU306479], L. aff. galriftensis [GenBank accession numbers EU306413-EU306414] and L. tevnianus [GenBank accession numbers EU306389EU306390 and EU306395-EU306396 for L. aff. tevnianus (Johnson et al., 2008)] were included. A published sequence of Peltospira delicata [GenBank accession number AY923931] was also included.

\section{Biodiversity measurements}

For both the global and regional analyses, the species richness $(S)$, the average taxonomic distinctness $\left(\Delta^{+}\right)$, and the Jaccard coefficient were calculated from species presence/absence matrices using the DIVERSE subroutine in PRIMER v5 (Clarke \& Warwick, 2001).

The average taxonomic distinctness $\left(\Delta^{+}\right)$is the average taxonomic distance between all pairs of species ( $i$ and $j$ ) in a sampling unit by tracing these distances through a taxonomic tree such as (Warwick \& Clarke, 2001):

$\Delta^{+}=\left[\Sigma \Sigma_{i<j} \omega_{i j}\right] /[S(S-1) / 2]$,

where $\omega_{\mathrm{ij}}$ is the 'distinctness weight' given to the path length linking species $\mathrm{i}$ and $\mathrm{j}$ in the hierarchical classification, $S$ is the total number of species in the sampling unit, and the double sum is over all pairs of species. Five taxonomic levels were considered: species, genus, family, order and class. Since equal step-lengths were assumed between successive taxonomic levels and the path length $\omega$ was set to 100 for two species connected at the highest taxonomic level, the weights are $\omega_{\mathrm{ij}}=20$ (species in the same genus), 40 (same family but different genera), 60 (same order but different families), 80 (same class but different orders) and 100 (different classes). For semi-quantitative collections performed in mussel beds along the SEPR, this index was then tested by comparing them to the distribution of the expected values of $\Delta^{+}$under the null hypothesis that sampling units are a random collection of the regional species pool. These expected values were generated for a given number of species $(S)$ after 1000 re-samplings of the dataset for each $S$ value. The 
regional species list is that of the species found in mussel beds along the whole SEPR, adding species from this study and from Van Dover $(2002,2003)$. In the context of this study, the main advantage of this index is that it is independent of sample size or sampling effort.

Pielou's evenness $\left(J^{\prime}\right)$, Shannon-Wiener diversity index $\left(H^{\prime}\right)$ and rarefaction index $E S_{(n)}$ were calculated for each mussel bed sampling unit from species relative abundance matrices using the DIVERSE subroutine in PRIMER v5. The $E S_{(n)}$ rarefaction index estimates the expected number of species (ES) in normalized sampling units of $n$ individuals from a larger real sample of $S$ species and $N$ individuals (Hurlbert, 1971). It was originally designed to allow comparisons of species diversity from sampling units of very different sizes. This method assumes that sampling units are homogeneous with similar distributions of individuals among species and that the species are randomly distributed. These assumptions are rarely observed in practice, so that the rarefaction index will be strongly biased for small samples. In our case, the sampling units were normalized to the smallest common number of individuals, i.e. 600 found at Grommit (2133' S) (Table 1).

\section{Multivariate statistical analyses}

Prior to multivariate analyses, a Hellinger transformation was applied to the species' response data. The transformation consists of dividing each species' presence value (1) by the total number of species at the site, or the abundance by the sum of the species present at the site, and then taking the square root of the ratio. After this transformation, Euclidean methods of analysis such as multivariate regression tree (MRT) and canonical redundancy analysis (RDA) (described below) will preserve the Ochiai distance among sites for presence-absence data, or the Hellinger distance among sites for abundance data. These distances are more appropriate than the Euclidean distance for ordination or MRT analysis of community composition data (Legendre \& Gallagher, 2001). All calculations were done through R language functions (R Development Core Team, 2006).

\section{Global analysis of communities along the EPR}

For the global analysis, putative biogeographic breaks were identified using a multivariate regression tree (MRT) (De'ath, 2002) computed for two different datasets: (1) the species list recorded in Desbruyères et al. (2006b), and (2) this list completed with the species collected during the BIOSPEEDO cruise (Appendix S1). This method was used to define groups of fields that are similar in faunal composition while geographically adjacent. The MRT is a partitioning method of the multivariate response data table (i.e. species) constrained in the present study along the axis of a single explanatory variable, i.e. the latitude, to generate spatially consistent groups of neighbouring fields. The tree structure is generated by partitioning the whole dataset into mutually exclusive groups. It is grown by successive binary splits of the data, each split involving a breakpoint in the latitude variable. Each split is chosen to minimize the total multivariate sum of squares within the two groups formed, or maximise the $R^{2}$ (or equivalently the among-group sum-of-squares) at each division step. The tree with the lowest cross-validation error was chosen as the best predictive tree. At the end of the procedure, each leaf of the tree is characterized by a number of sites, the multivariate mean of the sites, and the explanatory variable values that define it. The tree was computed using the 'mvpart' library (De'ath, 2002) in the R statistical language (R Development Core Team, 2006).

Since the latitudinal gradient is bounded by geographic barriers (i.e. the North American plate in the north and the Easter Island microplate in the south, Fig. 1), the species distribution was compared to predicted data according to the geometry theory of species richness (Colwell \& Lees, 2000). In response to geometric constraints, mid-domain effect (MDE) models predict for a bounded geographical domain a convex, symmetrical pattern of species richness in the absence of any additional environmental effect or other gradient. The 
predicted species richness was computed using the RangeModel program (version 5, R.K. Colwell, http://viceroy.eeb.uconn.edu/rangemodel) following the one-dimensional discrete null model developed by Dunn et al. (2006) to account for gaps in species ranges. The 95\% confidence interval was computed after 9999 randomizations. To assess the role of MDE on species richness, we computed a MRT using the species richness values predicted by the MDE null model as an explanatory variable in addition to the previously used geographic variable.

Variation of the macrofaunal community structure associated with mussel beds along the SEPR

To investigate the correlations of faunal composition with explanatory variables and identify putative geographic breaks, a canonical redundancy analysis (RDA) and a MRT were computed on the Hellinger-transformed abundance data of the macrofauna associated with mussel beds along the SEPR. The RDA combines aspects of ordination and regression and uses a permutation procedure to test the significance of the explained variation; thus species abundances do not have to be normally distributed (Legendre \& Legendre, 1998). The explanatory variables were the latitude from the equator, the geodynamic environment (twostate variable: tectonic vs. volcanic), the type of venting (three-state variable: $1=$ moribund, $2=$ diffusion zone, or $3=$ chimney wall) and the proportion of juvenile mussels (i.e. $<10 \mathrm{~mm}$ ). Forward selection of the environmental variables was conducted to select a parsimonious model. Permutation tests involving 999 permutations were run to test the significance of the canonical relationship and of the individual canonical axes. The redundancy analysis was computed using the rdaTest() function of the 'rdaTest' package available on the page http://www.bio.umontreal.ca/legendre/.

In order to group the sampling units collected from the mussel beds according to their faunal composition, the chord distance was calculated between the sampling units from the relative species abundance data. This measure is similar to the Euclidean distance after normalization of the site vectors and is thus more appropriate when the sampling area is variable among sampling units. The sites were then clustered using the unweighted pairgroup method with arithmetic averages (UPGMA). This method was chosen because it gave the highest correlation between the chord distances and the cophenetic matrix corresponding to the dendrogram (i.e. containing the levels at which sampling sites $\mathrm{i}$ and $\mathrm{j}$ become members of the same cluster). Hierarchical clustering was computed using the hclust() function of the 'stats' package in $\mathrm{R}$.

\section{Results}

\section{Global analysis of the vent fauna along the EPR}

The BIOSPEEDO cruise added 18 species to the list reported in Desbruyères et al. (2006b) leading to a final list of 96 species along the whole EPR (Appendix S1). Data acquired during the BIOSPEEDO cruise extended the geographic range of most gastropod and polychaete species that had been previously reported from the northern EPR (Warén \& Bouchet, 2001, Desbruyères et al. 2006b). As an example, Lepetodrilus tevnianus, only recorded previously at $11^{\circ} \mathrm{N}$, was collected at $13^{\circ} 59^{\prime} \mathrm{S}, 17^{\circ} 25^{\prime} \mathrm{S}$, and $21^{\circ} 33^{\prime} \mathrm{S}$. L. cristatus, previously recorded at $21^{\circ} \mathrm{N}, 13^{\circ} \mathrm{N}$, and from the Galápagos, was found at $13^{\circ} 59^{\prime} \mathrm{S}$ and $21^{\circ} 33^{\prime} \mathrm{S}$. Similarly, Echinopelta fistulosa and Cyathermia naticoides, only known from the northern EPR (i.e. $9^{\circ}$ $\mathrm{N}$ to $21^{\circ} \mathrm{N}$ ), were collected at $21^{\circ} 33^{\prime} \mathrm{S}$ and $17^{\circ} 25^{\prime} \mathrm{S}$, respectively. Furthermore, this cruise led to the discovery of 10 new morphospecies, i.e. Phymorhynchus $\mathrm{n}$. sp. at $17^{\circ} 25^{\prime} \mathrm{S}$ and $18^{\circ} 36^{\prime} \mathrm{S}$, Melanodrymia n. sp. and Haloceras n. sp. at $21^{\circ} 33^{\prime} \mathrm{S}$ for gastropods (A. Warén, 
pers. obs.), and Paralvinella n. sp., Glycera n. sp. and a new Ampharetidae species at $21^{\circ} 33^{\prime}$ S, Sphaerodopsis n. sp. at $18^{\circ} 36^{\prime} \mathrm{S}$, Nicomache n. sp. and a new species of Flabelligeridae at $17^{\circ} 25^{\prime} \mathrm{S}$ and $21^{\circ} 33^{\prime} \mathrm{S}$, and Oasisia n. sp. between $7^{\circ} 25^{\prime} \mathrm{S}$ and $17^{\circ} 25^{\prime} \mathrm{S}$ for polychaetes (D. Desbruyères \& S. Hourdez, pers. obs.). Haloceras is also a new genus for hydrothermal vents. These new species were only found south of the latitude of $17^{\circ} 25^{\prime} \mathrm{S}$. Two species that belong to genera characterizing other ridge systems (i.e. Eosipho auzendi from the Pacific Antarctic Ridge and Shinkailepas sp., a genus previously known from the Mid-Atlantic Ridge and back-arc basins) were also reported. Moreover, the gastropods Nodopelta heminoda and $N$. subnoda and the polychaete Hesiolyra bergi, highly abundant on the chimney walls of the NEPR vent fields, were virtually absent (very few individuals) from SEPR sampling units despite an intense sampling effort (9 chimneys extensively sampled).

When analysing only the species dataset reported in the Handbook of deep-sea hydrothermal fauna (Desbruyères et al., 2006b), species richness was twice as high at all NEPR vent fields (i.e. 42 to 62 species) than at any vent field from SEPR (i.e. 13 to 28 species) (Table 3). The highest species richness was observed at $13^{\circ} \mathrm{N}$ and $21^{\circ} \mathrm{N}$ (i.e. 62 and 51 , respectively) for NEPR and at $17^{\circ} 25^{\prime} \mathrm{S}$ (i.e. 28) for SEPR. Average taxonomic distinctness was nearly homogeneous along the whole EPR with the highest value (84.48) found at $17^{\circ} 25^{\prime} \mathrm{S}$. Adding the species sampled during the BIOSPEEDO cruise significantly increased the number of species recorded in the SEPR to an extent similar to that of the NEPR. The analysis revealed two centres of species diversity: one in the north including $21^{\circ}$ $\mathrm{N}$ and $13^{\circ} \mathrm{N}$ and one in the south comprised of the vent fields between $17^{\circ} 25^{\prime} \mathrm{S}$ and $21^{\circ} 33^{\prime}$ $\mathrm{S}$. Species richness in the SEPR reached 60 at $17^{\circ} 25^{\prime} \mathrm{S}$ as opposed to 62 at $13^{\circ} \mathrm{N}$. The average taxonomic distinctness was not affected greatly, with the highest value still found along the SEPR (Table 3). The empirical species richness does not display a mid-domain peak as predicted under the MDE model. Indeed, 6 out 9 hydrothermal vent fields fell out of the $95 \%$ confidence interval of values predicted by the model (Fig. 2).

The multiple cross-validations produced a MRT with three groups of fauna for both analyses, explaining $70.3 \%$ of the variation in the species dataset when considering only the handbook data and $45.4 \%$ when adding the new species records (Fig. 3). Those trees displayed the lowest cross-validation error and offered sufficient resolution when considering the number of observed hydrothermal fields along the EPR (i.e. 9). The first split separated the northern and southern parts of the EPR near the equator. A second split subdivided the SEPR into two groups of assemblages: south of latitude $17^{\circ} 35^{\prime} \mathrm{S}$ when only considering the species reported in the handbook, and south of latitude 13 $59^{\prime} \mathrm{S}$ when the species collected during the BIOSPEEDO cruise were added to the analysis. Adding the predicted species richness under the MDE model as an explanatory variable did not improve the tree resolution (detailed results not shown).

\section{Evidence of species crypticism and vicariance in vent gastropods}

Phylogenetic relationships were analysed for 14 species of Lepetodrilidae, Neolepetopsidae, Neomphalidae and Peltospiridae gastropods along the whole EPR using a 425 bp sequence portion of the cytochrome $\mathrm{c}$ oxidase subunit I (COI). The COI sequences correspond to the accession numbers from GU984234 to GU984303 in GenBank. The tree obtained by Bayesian inference is presented in Fig. 4. All nodes with less than a 95\% probability were collapsed to basal polytomy. Within the Lepetodrilidae family, we detected thirteen clades with ten clades involving five species of the genus Lepetodrilus. The two species of the genus Gorgoleptis, Lepetodrilus cristatus and Clypeosectus delectus were the only species not subdivided into two sister clades. However, both the Gorgoleptis and Clypeosectus species were only collected from the SEPR while only L. cristatus individuals from $13^{\circ} \mathrm{N}$ were available for molecular analysis. Pairwise K2P distances (Kimura, 1980) between clades detected within each well-identified morphological species, i.e. L. elevatus, L. pustulosus, $L$. ovalis, L. cristatus and L. tevnianus, ranged between $1.5 \%$ and $8.3 \%$. Within cryptic lineages (i.e. clades), pairwise distances ranged from 0 to a maximum of $1.5 \%$. Lepetodrilus aff. 
galriftensis, identified by Johnson et al. (2008), grouped with the southern clade $\left(9^{\circ} 50^{\prime} \mathrm{N}\right.$ to $21^{\circ} 33^{\prime} \mathrm{S}$ ) of Lepetodrilus elevatus (Matabos et al., 2008a; Plouviez et al., 2009) and Lepetodrilus aff. elevatus (Johnson et al. 2008) with the third clade only found at $21^{\circ} 33^{\prime} \mathrm{S}$. This latter diverged from the northern and southern clades by $7 \%$ and $5.8 \%$ respectively. $L$. ovalis also displayed two clades with a slight divergence of $1.5 \%$. The two clades of $L$. tevnianus and L. pustulosus diverged by 6.2 and $9.2 \%$ respectively. In Neolepetopsidae, Eulepetopsis vitrea also displayed two distinct geographic mitochondrial lineages separated by a divergence of $1.5 \%$ and located on either side of the equator. Within the Peltospiridae and Neomphalidae, Peltospira operculata and Pachydermia laevis exhibited two to three divergent clades. Peltospira operculata and Pachydermia laevis showed the strongest divergence between the NEPR and SEPR with $7.9 \%$ and $12.5 \%$ divergence between the two clades, respectively. An individual of $P$. laevis sequenced from $31^{\circ} \mathrm{S}$ beyond the Easter microplate showed $10.8 \%$ divergence with the NEPR clade and $11.2 \%$ with the SEPR, respectively. For those two species, pairwise K2P distances within cryptic clades ranged from $0.2 \%$ to $0.6 \%$.

Except for Lepetodrilus ovalis, cryptic lineages within a single morphological species were geographically structured with a northern and southern lineage across the equator and, in a few cases an additional mitochondrial lineage at the southernmost vent field (i.e. $21^{\circ} 33^{\prime}$ $\mathrm{S})$. The absence of sampling units between $9^{\circ} 50^{\prime} \mathrm{N}$ and $17^{\circ} 25^{\prime} \mathrm{S}$ for several taxa makes impossible a clear identification of the location of the geographic break along the ridge. Furthermore, as it was impossible to identify lineages on the basis of morphological criteria, the species complexes identified here were not subjected to further biogeographic analyses.

\section{Variations in the macrofaunal community structure of mussel beds along the SEPR}

Up to 13,339 individuals belonging to 61 species were collected in mussel beds along the SEPR: 28 species of gastropods (19 genera and 11 families), 31 species of polychaetes (22 genera and 15 families), and 2 species of echinoderms ( 2 genera and 2 families) (Table 4). The most abundant species at the regional scale were Lepetodrilus spp. (i.e. L. elevatus and L. ovalis), Eulepetopsis vitrea, Amphisamytha galapagensis and Archinome rosacea. While Melanodrymia aurantiaca was only found at $21^{\circ} 33^{\prime} \mathrm{S}$, it was highly abundant at that site because mussels colonized an active black smoker. Conversely, Planorbidella cf. planispira was found in most sampling units but with few individuals at each locality. Local species richness varied between 11 and 27, with the lowest values observed at Lucky Eric (13'59' S), Susie $\left(17^{\circ} 34^{\prime} \mathrm{S}\right)$ and Sarah's Spring $\left(7^{\circ} 25^{\prime} \mathrm{S}\right)$ (Table 5). The highest species diversities, both in terms of species richness and rarefaction index, were observed at the $17^{\circ} 25^{\prime} \mathrm{S}$ Rehu Marka, 18 ${ }^{\circ} 36^{\prime} \mathrm{S}$ Animal Farm and $21^{\circ} 33^{\prime} \mathrm{S}$ Grommit sites. However, Shannon indices are relatively low, ranging between 0.53 at Susie and 2.40 at Rehu Marka (Table 5).

The average taxonomic distinctness index $\Delta^{+}$varied between 67.20 for Lucky Eric $\left(13^{\circ} 59^{\prime} \mathrm{S}\right)$ and 88.84 for Animal Farm (18 $\left.36^{\prime} \mathrm{S}\right)$. The following highest values, observed for collections

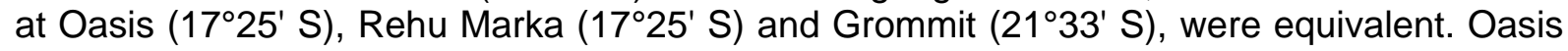
$\left(17^{\circ} 25^{\prime} \mathrm{S}\right)$, Rehu Marka $\left(17^{\circ} 25^{\prime} \mathrm{S}\right)$, Animal Farm (18 $\left.36^{\prime} \mathrm{S}\right)$, and one replicate from Grommit (i.e. Gr2, $21^{\circ} 33^{\prime} \mathrm{S}$ ) were significantly higher than the theoretical value estimated by 1000 permutations of the dataset. The sampling unit collected at Lucky Eric (13 $\left.59^{\prime} \mathrm{S}\right)$ was significantly smaller in terms of average taxonomic distinctness (Fig. 5).

The UPGMA dendrogram in Fig. 6 shows a clear separation of sampling sites into three distinct groups, plus one isolated site, Sarah's Spring $\left(7^{\circ} 25^{\prime} \mathrm{S}\right)$. Sarah's Spring was characterized by low species richness and taxonomic diversity, with the absence of echinoderms and the presence of six species of polychaetes. This site differs from others because the gastropod Lepetodrilus pustulosus, almost absent from other sampling units, was found in high proportion. Both L. pustulosus and the polychaete Amphisamytha galapagensis accounted for $85 \%$ of the individuals collected. The first group on the dendrogram corresponds to the highest values of the Shannon diversity index and high average taxonomic distinctness (Table 5). It includes Animal Farm (18 ${ }^{\circ} 36^{\prime} \mathrm{S}$ ) and Rehu 
Marka $\left(17^{\circ} 25^{\prime} \mathrm{S}\right)$, which contained five and seven dominant species, respectively (i.e. $>5 \%$ of individuals). The second group, which includes collections from Lucky Eric (13⒌ $\mathrm{S}$ ), Oasis BS6 $\left(17^{\circ} 25^{\prime} \mathrm{S}\right)$ and Susie $\left(17^{\circ} 34^{\prime} \mathrm{S}\right)$, had the lowest Shannon diversity index (Table 5). These collections mainly composed of lepetodrilid species, with $L$. elevatus present up to $88 \%$ and $90 \%$ in the sampling units collected at Oasis BS6 and Susie, respectively. Finally, sampling units collected at Grommit $\left(21^{\circ} 33^{\prime} \mathrm{S}\right)$ formed a single group with $65 \%$ species similarity. They displayed the same species and taxonomic diversity and contained at least three new species each, and six new species only shared by these sampling units (i.e. Melanodrymia n. sp., Shinkailepas sp., Glycera n. sp., Nichomache n. sp., Oasisia n. sp. and the new species of Ampharetidae).

The sites and the explanatory variables used in RDA are displayed in an ordination biplot in Fig. 7. Results of the RDA showed that, after forward selection, the transformed species abundances were significantly correlated with two environmental variables out of four: the latitude and the type of venting (i.e. moribund state) $\left(R^{2}\right.$ adj $\left.=0.28, P=0.0004\right)$. The first axis accounted for $27.6 \%(P=0.001)$ of the total variation in species abundance data. The biplot also shows the 4 groups of fields from Fig. 6 . The MRT analysis produced the same exact patterns of faunal distributions as that obtained from the global analysis performed along the whole EPR from the presence/absence dataset (results not shown).

\section{Discussion}

The specialized nature of vents and their geographic isolation on active spreading centres are interesting features for the study of vicariance, species dispersal and colonization pathways (Tunnicliffe, 1988). Two complementary approaches are commonly used in biogeography: historical and ecological biogeography. While ecological biogeography investigates the current mechanisms of communication and dispersion at the regional scale, historical biogeography studies the role of tectonic/climatic events that have led to the formation or dislocation of geographic barriers. When considering oceanic ridges at a global scale, tectonic events, creating physical barriers such as transform faults or microplates, can lead to the isolation of species in allopatry (i.e. vicariant species). This process has been suggested to be an important driving force of vent fauna evolution (Tunnicliffe \& Fowler, 1996; Tunnicliffe et al., 1998). Ecological biogeography studies the factors that define the spatial distributions of species in the present time, thus the processes acting at regional to local scales (Monge-Najera, 2008). Local factors do not only act at the community level but can also have broader significance. As an example, at the vent scale, spatial habitat heterogeneity, related to spatial variation in fluid fluxes, results in the occurrence of multiple micro-habitats at the centimetre scale (Sarrazin et al., 1997; Mills et al. 2007) and could promote sympatric speciation. This process, also called ecological speciation, has been suggested to fix divergence c. 20 times faster than species formation in allopatry but is rarely observed in nature (Via, 2001; Briggs, 2006). On the other hand, local processes influencing community structure and biodiversity patterns can blur broader biogeographical patterns if a non-adapted sampling strategy is used (e.g. too few sampling units and/or replicates, given the scope of the study). Ecology and biogeography are thus complementary approaches in order to understand biodiversity patterns (Briggs, 2007).

\section{Evidence of crypticism in gastropod species}

For the lepetodrilid species, $6.5 \%$ divergence has already been shown for Lepetodrilus elevatus separating the northern and southern clades found in sympatry at $9^{\circ} 50^{\prime} \mathrm{N}$ (Matabos et al., 2008a). Johnson et al. (2008) also revealed several distinct cryptic species complexes within the genus Lepetodrilus with pairwise COI distances ranging between 4.37 and $31.25 \%$. Pachydermia laevis displayed haplotypes with $12.5 \%$ divergence between the 
northern and southern EPR, higher than the divergence found with individuals collected on the other side of the Easter microplate. The level of sequence divergence between haplotypes of Peltospira operculata found on either side of the equator fell in the same range as that of the lepetodrilids with $7.9 \%$ divergence. Moderate genetic divergences (0.9 to 1.5\%) between geographically-structured northern and southern EPR populations were detected for other taxonomic groups including bivalves and polychaetes (Plouviez et al., 2009). While levels of divergence can be highly variable between sets of sibling species (Knowlton, 2000), pairwise genetic distances between and among clades highlighted in this study fit inter- and intra-specific levels previously described from closely-related species (Peek et al., 1997), highlighting the occurrence of two new cryptic species complexes along the EPR, i.e. $P$. laevis and $P$. operculata. Since the development of molecular techniques, occurrence of sibling species appears to be more widespread in hydrothermal ecosystems, and at a broader scale, in the sea (Knowlton, 2000; Johnson et al., 2008; Matabos et al., 2008a; Vrijenhoek 2009).

\section{Biogeographic entities along the EPR}

Barcoding of hydrothermal species (Johnson et al., 2008), population genetics studies (e.g. Chevaldonné et al., 2002; Won et al., 2003; Hurtado et al., 2004; Matabos et al., 2008a) and comparative phylogeography (Plouviez et al., 2009) along the EPR converge to the existence of a genetic break near the equator at the scale of the whole vent community. Several topographic features, related to ridge history, have been proposed to explain the divergence observed between cryptic species. The formation of the Bauer microplate, 17-6 Ma (Matabos et al., 2008a), and the fossilization of the Mathematician ridge (Plouviez et al., 2009) at about the same time, were proposed to account for the divergence observed in the split of Lepetodrilus elevatus into two cryptic lineages. Four out of five lepetodrilid species display the same range of genetic divergence (i.e. 5.2 to 9.2\%; Johnson et al., 2008; Matabos et al., 2008a; this study) and may thus share the same past history. However, levels of divergence are variable among species with two sets of values ranging from $6-12 \%$ (an 'old' vicariant event involving Lepetodrilus elevatus, L. pustulosus, L. tevnianus, Peltospira operculata and Pachydermia laevis) to $1.5-3 \%$ (a more 'recent' tectonic event at the equator involving $E$. vitrea but also Alvinella pompejana, Bathymodiolus thermophilus and Hesiolyra bergi: see Plouviez et al., 2009), respectively. Tests on shared divergence times performed on seven hydrothermal vent species along the EPR by Plouviez et al. (2009) revealed the occurrence of a common vicariant event $\sim 1.3 \mathrm{Ma}$ for all studied species, including $L$. elevatus for which another older speciation event is also detected around $11.5 \mathrm{Ma}$. These latter authors therefore proposed that the formation of transform faults around 1 to $2 \mathrm{Ma}$ between $4^{\circ} \mathrm{S}$ and $14^{\circ} \mathrm{S}$, may be responsible for this vicariant break and the emergence of a transition zone in this area.

Analyses of community composition expressed in terms of presence/absence support the molecular dataset. Recently, Bachraty et al. (2009) suggested that the EPR is separated into two different biogeographic provinces: the NEPR and the SEPR. Our MRT analyses confirmed the presence of a geographic break at the equator separating the EPR fauna into two biogeographic entities with one major split near the equator, somewhere between $9^{\circ} 50^{\prime}$ $\mathrm{N}$ and $4^{\circ} \mathrm{S}$. A secondary split being more precisely located around $15^{\circ} \mathrm{S}$ separates the SEPR in two smaller entities. However, species lists and molecular data between $9^{\circ} 50^{\prime} \mathrm{N}$ and $7^{\circ} 25^{\prime} \mathrm{S}$ are lacking and further studies centred on the Hess Deep are needed to exactly localize the break. The two evolutionary lineages of Lepetodrilus elevatus were found in sympatry at $9^{\circ} 50^{\prime} \mathrm{N}$ and are able to hybridize (Matabos et al., 2008a). Other cryptic complex species may also overlap around the equator. This is especially the case for Lepetodrilus ovalis, which showed a consistent but weak divergence between two distinct mitochondrial lineages that overlap along the SEPR. In contrast, the gastropod E. vitrea, which displays the same level of divergence, exhibits a complete geographic separation of its two cryptic lineages at $7^{\circ} 25^{\prime} \mathrm{S}$ in a way similar to the polychaete $A$. pompejana (Plouviez et al., 2009). 
One explanation could be the differences in life history strategies that can influence dispersal abilities. Some species may indeed have a dispersal potential to cross the barrier and meet secondarily. Genome homogenization between the previously isolated clades then depends on the strength of the selection against hybrids (genetic barrier: Barton \& Hewitt, 1985).

Added to the occurrence of cryptic species in the two parts of the EPR, the BIOSPEEDO cruise brought at least ten new species for hydrothermal vents (three gastropods, seven polychaetes) and expanded the range of several species previously described from the NEPR. The wide geographic range of most vent species confirmed findings from studies previously conducted by Van Dover (2002) in the same area. However, while the first studies based on megafauna observations (Geistdoerfer et al., 1995; Halanych et al., 1999) and the quantitative analysis of communities associated with mussel beds (Van Dover, 2002, 2003) concluded that the fauna was similar between the northern and southern EPR, results from the present study highlighted several latitudinal changes in community composition between $17^{\circ} \mathrm{S}$ and $21^{\circ} \mathrm{S}$. New species were found beyond $17^{\circ} \mathrm{S}$ and some species warrant further study as their identification remains uncertain (Hourdez \& Desbruyères; A. Warén, pers. obs.). In the listed taxa, two species, Shinkailepas sp. and Eosipho auzendi, represented by two and more individuals, respectively, belong to a genus so far known only from the MidAtlantic Ridge and the Northwest Pacific back-arc basins for Shinkailepas sp. (Desbruyères et al., 2006b). The presence of Eosipho was previously reported at Rehu Marka by Van Dover (2002). Added to the presence of at least five cryptic species (i.e. Lepetodrilus elevatus, L. pustulosus, L. tevnianus, Peltospira operculata, Pachydermia laevis), the East Pacific Rise appears to be a more complex biogeographic zone than was first suggested. When taking into account only the species recorded in Desbruyères et al. (2006b), a geographic break was found at $18^{\circ} \mathrm{S}$ (Fig. 3a) and while taxonomic diversity was higher at $17^{\circ} 25^{\prime} \mathrm{S}$, the highest species richness was found at $13^{\circ} \mathrm{N}$ (Table 3 ). When combining species collected on the SEPR during the BIOSPEEDO cruise, both species richness and taxonomic diversity were no longer different between the NEPR and SEPR vent sites and the geographic break along the SEPR appeared between $14^{\circ} \mathrm{S}$ and $17^{\circ} 25^{\prime} \mathrm{S}$. The hypothesis of Bachraty et al. (2009) that the NEPR could be a centre of dispersal is probably due to oversampling in the northern part of the EPR. Indeed, the uneven sampling effort performed across hydrothermal vent ecosystems since their discovery, resulting from the poor accessibility of the vent environment, may well have generated biases in the data that led to incorrect derived biogeographic patterns. This may still be the case for underexplored regions such as the Pacific Antarctic Ridge and the Indian Ridge. We can, however, expect that biodiversity of macrofauna is now well estimated for the most prospected regions, i.e. the northern East-Pacific Ridge, the Western Pacific back-arc basins or the Azorean plateau of the Mid-Atlantic Ridge. Observations and molecular data led to the assumption that the high species diversity observed in the southern part of the SEPR is the result of the overlap of several distinct biogeographic provinces. The new species of Phymorhynchus sp. had already been found at $31^{\circ} \mathrm{S}$ (A. Warén, pers. obs.) in concordance with the presence of the gastropod Eosipho auzendi, described from the Pacific Antarctic Ridge. Individuals of Shinkailepas sp., a genus only described on the Mid-Atlantic Ridge and in the back-arc basins, were encountered at $21^{\circ} 33^{\prime} \mathrm{S}$. Furthermore, the average taxonomic distinctness for the sampling units collected in mussel beds located between $17^{\circ} 25^{\prime} \mathrm{S}$ and $21^{\circ} 33^{\prime} \mathrm{S}$ (i.e. Oasis BS6, Rehu Marka, Animal Farm and Grommit) are above the upper limit of the 95\% confidence interval of the simulated values, reinforcing the hypothesis of an abnormal hot spot of diversity in this area. Similarly, the observed species richness values differ significantly from the predicted richness under the mid-domain effect null model, which predicts expected species richness values by considering the geometric constraints on the geography (Colwell \& Lees, 2000). Those results suggest that the southern part of the SEPR (i.e. between $17^{\circ} 25^{\prime} \mathrm{S}$ and $21^{\circ} 33^{\prime} \mathrm{S}$ ) probably forms a transition (mixing) zone between the NEPR, the Pacific Antarctic Ridge, and possibly the back-arc basins of the western Pacific. This assumption is supported by the co-occurrence of NEPR-like Alvinella colonies and Chorocaris sp. swarms at $21^{\circ} 33^{\prime} \mathrm{S}$, these shrimp swarms being one of the most striking characteristics of the Mid-Atlantic Ridge, the Indian Ocean Ridge and the western Pacific 
back-arc basins (Van Dover et al., 2001; Jollivet et al., 2005). The latitudinal gradient in species diversity revealed the influence of tectonic plates and ridge history but only accounted for $45.4 \%$ of the total variation of the species presence/absence in vent assemblages, pointing out the need to combine historical and ecological biogeography for a better understanding of current biodiversity patterns.

\section{Biodiversity patterns at regional scale: mussel beds along the southern East Pacific}

\section{Rise}

Species diversity associated with mussel beds was analysed along the SEPR to better understand regional processes influencing community structure along the ridge. Diversity associated with mussel beds has been extensively studied along the East Pacific Rise (e.g. Turnipseed et al., 2003; Van Dover, 2003; Bergquist et al., 2005; Dreyer et al., 2005). Most of those studies were conducted using quantitative sampling that includes vagile epifauna and large macrofauna juveniles (e.g. crabs). This difference in sampling design can account for the lower species richness observed in this study compared to previous studies conducted along the SEPR (Van Dover, 2002, 2003). Results from the canonical analysis showed that latitude combined with the venting state at the regional scale is significantly correlated with the community structure and composition associated with mussel beds along the SEPR. The sites Oasis $\left(17^{\circ} 25^{\prime} \mathrm{S}\right)$, Rehu Marka $\left(17^{\circ} 25^{\prime} \mathrm{S}\right)$, Animal Farm $\left(18^{\circ} 36^{\prime} \mathrm{S}\right)$, and Grommit $\left(21^{\circ} 33^{\prime} \mathrm{S}\right)$ were characterized by high diversity when compared to the northernmost sites.

While the influence of the geodynamic environment was not significant, the analysis did show that the venting stage had a significant influence when combined with latitude. This result reflects the intermingling role of local and regional factors. The type of venting is strongly related to the regional dynamics of the ridge (Fouquet et al., 1994). All chimneys were found in vent fields characterized by a tectonic environment (i.e. Grommit-21 ${ }^{\circ} 33^{\prime} \mathrm{S}$ and Susie$\left.17^{\circ} 34^{\prime} \mathrm{S}\right)$. Areas driven by volcanic activity are less stable in time and space than tectonic areas (Fouquet et al., 1994). Those differences, by controlling the extinction rate of sites, will impact the extinction/recolonization rate of the vent fauna, promote habitat heterogeneity and reduce distances between sites (Jollivet et al. 1999). While unstable environments are expected to reduce species diversity by maintaining communities in a pioneer stage (Juniper \& Tunnicliffe, 1997), authors have suggested that the resulting small distances between vent sites should account for bursts of gene flow (Jollivet et al. 1999) and thus for a greater rate of site recolonization promoting higher species diversity (Turnipseed et al., 2003; Van Dover \& Doerries, 2005). Furthermore, if taxonomic distinctness is expected to be a more sensitive univariate index to community perturbation than species diversity (Warwick \& Clarke, 1995), species richness and taxonomic diversity were equivalent in the two types of vent dynamics, suggesting that differences resided mainly in species composition. As an example, three gastropod species (i.e. Melanodrymia aurantiaca, Echinopelta fistulosa and Nodopelta subnoda), known to colonize active black smoker chimney walls (Jollivet, 1996), were only collected at the Grommit site $\left(21^{\circ} 33^{\prime} \mathrm{S}\right)$ where mussel beds developed at the base and on the wall of a black smoker. Similarly, scavenger species (i.e. Phymorhynchus spp., Eosipho auzendi, Spioniphura jolliveti) were mainly found in sites located in volcanic areas (i.e. Oasis BS6, Rehu Marka and Animal Farm).

On the other hand, while all sampling units collected in the tectonic $21^{\circ} 33^{\prime} \mathrm{S}$ vent field (i.e. Grommit) were similar in species composition, strong differences were observed between sampling units at the volcanic $17^{\circ} 25^{\prime} \mathrm{S}$ area (i.e. Oasis BS6 and Rehu Marka). In unstable volcanic areas, the high rate of spatio-temporal changes in fluid fluxes result in the intermingling of different successional stages within a site, thus enhancing the variance among mussel beds in a given area. For example, at the declining site Sarah's Spring, located on a dome-shaped ridge, the presence of small specimens of the tubeworms Tevnia 
jerichonana and Oasisia sp. (D. Jollivet, pers. obs.) suggests the (re)start of a new venting site at the immediate periphery of an earlier vestimentiferan community.

The major effect of venting state on mussel beds community is due to the decline in hydrothermal activity (i.e. moribund state). Edifice life spans are highly variable within a single vent field in response to stochastic events altering fluid discharge and mineralization processes. Variations in fluid discharge intensity greatly influence physico-chemical variables and biotic interactions between species (Mullineaux et al., 2003), which will, in turn, greatly impact the community structure and composition. Species composition is thus highly variable in time and space within a single site and strong differences are observed according to the successional stage of the community at the time of sampling (Jollivet, 1996; Sarrazin et al., 1997; Shank et al., 1998). On the EPR, productivity, species richness and abundances of invertebrates associated with mussel beds appeared to be lower at waning and older sites than at young and active sites (Van Dover, 2003; Dreyer et al., 2005). In this study, the age of mussel beds was unknown and the temporal state of mussel beds was assessed via the demographic structure of mussel populations and the proportion of juveniles. No correlation has been found between community structure and the mussel size frequency distribution (unpublished data) or the proportion of juvenile mussels. This proportion was high at the declining site Animal Farm (i.e. 56\%, Table 1) while a low proportion of juveniles characterized the large and dense mussel beds developing in the healthy site Grommit $\left(21^{\circ} 33^{\prime} \mathrm{S}\right.$ ) (i.e. between 0 and $9 \%$ ). Thus the proportion of juvenile mussels does not appear to be a good proxy to characterize mussel bed conditions and did not reflect in situ observations of the vent community (e.g. presence of decaying vestimentiferan tubes at Sarah's Spring). Nevertheless, the apparent declining sites Sarah's Spring exhibited a low diversity, as expected from previous observations on mussel beds (Van Dover, 2003) with the overwhelming presence of the gastropod Lepetodrilus elevatus (48\%) and the polychaete Amphisamytha galapagensis (37\%). By contrast, the second declining site (i.e. Animal Farm) located on a dome-shaped ridge is characterized by a high diversity.

Latitudinal gradient and venting stage explained less than half of the variation in the species data, suggesting that other local biotic (e.g. predation, competition) or abiotic factors (e.g. small scale habitat heterogeneity) independent of the type of venting, as well as metacommunity neutral dynamic, may account for a large proportion of the observed variation. Manipulative field experiments showed that biological interactions, including facilitation and competition for space and/or food availability, could strongly modify the community structure in the absence of temporal changes in physico-chemical conditions (Micheli et al., 2002; Mullineaux et al., 2003). Similarly, recent studies suggested that most hydrothermal gastropod species are not exclusive to a specific habitat type as they may occupy specific microhabitats (Mills et al., 2007; Matabos et al., 2008b). However, despite the lack of replicate sampling units, the influence of local factors is not sufficient to totally blur the effects of regional and global factors related to the latitudinal gradient.

\section{Limitations and issues}

The recent discovery of cryptic species following the emergence of barcoding approaches and molecular taxonomy raises the problem of species identification and thus the assessment of vent biodiversity (Vrijenhoek, 2009). This appears to be a general issue in the marine environment. Ubiquitous species are frequent among marine invertebrates and vertebrates, and are often found over a wide range of latitudes from the poles to the tropics (Knowlton, 1993). Good species identification is needed to understand vent community history, colonization pathways, and the origin(s) of the fauna. Those observations reinforce the importance of comparative phylogeography to complement analytical approaches of historical biogeography (Arbogast \& Kenagy, 2001). Correct assessments of species boundaries are fundamental to the testing of biogeographic hypotheses (Palumbi, 1996). Furthermore, species identifications are not always conducted by specialists, a fact that leads to difficulties in comparisons between taxa lists. Valid comparisons across studies 
require a standardized process for the identification of organisms. This raises another issue related to species recording and species distribution areas and the validity of lists available in the literature. Individuals identified by acknowledged specialists and recorded in a museum with a barcode and a voucher number appear to be a safe standard for biodiversity assessment and record. However, ecological studies are more numerous than taxonomic ones and numerous species lists are provided by ecologists (Van Dover, 2002, 2003; Governar et al., 2005; Matabos et al., 2008b), making it very difficult to assess the real biodiversity associated with each of the EPR segments. Differences in sampling methods (i.e. quantitative vs. qualitative) can also account for the differences observed. Sampling devices have been independently developed in the different laboratories and may thus not be comparable. Finally, the status of rare species should also be seriously considered in biogeographic approaches. Most ecological studies focus on a particular vent habitat, and, as a result, may underestimate the 'real' local biodiversity. To our knowledge, the sediment habitat surrounding vents has been greatly neglected, so that many species may have never been collected.

This study not only reinforces the existence of two biogeographic provinces along the East Pacific Rise, the northern and the southern EPR, but also suggests that the 'abnormal' high species diversity associated with the southern part of the SEPR $\left(17^{\circ} \mathrm{S}-21^{\circ} \mathrm{S}\right)$ could result from an overlap of several biogeographic entities. Additional samples from the poorly explored Pacific Antarctic Ridge area could help in the understanding of biodiversity patterns associated with the Pacific hydrothermal vent systems. Combining species diversity analyses with comparative phylogeography will help unveil colonization pathways that have led to the present species distribution. On the other hand, the lack of standards in species classification for deep-sea biogeography and the cross-validation of species identification can explain the discrepancy observed when comparing studies conducted in the same parts of the ocean. The analysis of diversity associated with mussel beds was a first step towards a greater understanding of the role of global, regional, and local factors on biodiversity patterns. In this study a combination of the latitudinal gradient and the venting stage significantly influenced the community structure, but more replicates and explanatory variables are needed to ascertain such an assumption. This study will help in the design of future macroecology studies along the EPR which aim to understand processes influencing the distribution of biodiversity.

\section{Acknowledgements}

We thank the crew and pilots of the RV L'Atalante and the DSV Nautile for their assistance and technical support during the cruise BIOSPEEDO '04. We also thank the sequencing/genotyping platform GENOMER for $\mathrm{COI}$ sequence acquisition. We are grateful to Candice St Germain for the English proofreading. This work was financially supported by the GDR Ecchis and the ANR Biodiversité 'Deep Oases' (ANR-06-BDIV-005). A grant from the European SYNTHESIS Project funded the collaboration with the Swedish Museum of Natural History.

\section{References}

Arbogast, B.S. \& Kenagy, G.J. (2001) Comparative phylogeography as an integrative approach to historical biogeography. Journal of Biogeography, 28, 819-825.

Auzende, J.-M., Ballu, V., Batiza, R., Bideau, D., Cormier, M.-H., Fouquet, Y., Geistdoerfer, P., Lagabrielle, Y., Sinton, J. \& Spadea, P. (1994) Activité magmatique, tectonique et hydrothermale actuelle sur la dorsale est Pacifique entre $17^{\circ} \mathrm{S}$ et $19^{\circ} \mathrm{S}$ (campagne Naudur). Comptes Rendus de l'Académie des Sciences, série II, 319, 811-818. 
Bachraty, C., Legendre, P. \& Desbruyères, D. (2009) Biogeographic relationships among deep-sea hydrothermal vent faunas at global scale. Deep-Sea Research I, 56, 1371-1378.

Barton, N.H. \& Hewitt, G.M. (1985) Analysis of hybrid zones. Annual Review of Ecology and Systematics, 16, 113-148.

Bergquist, D.C., Fleckenstein, C., Knisel, J., Begley, B., McDonald, I.R. \& Fisher, C.R. (2005) Variations in seep mussel bed communities along physical and chemical environmental gradients. Marine Ecology Progress Series, 293, 99-108.

Briggs, J.C. (2006) Proximate sources of marine biodiversity. Journal of Biogeography, 33, 110.

Briggs, J.C. (2007) Marine biogeography and ecology: invasions and introductions. Journal of Biogeography, 34, 193-198.

Chevaldonné, P., Jollivet, D., Desbruyères, D., Lutz, R.A. \& Vrijenhoek, R.C. (2002) Sisterspecies of eastern Pacific hydrothermal vent worms (Ampharetidae, Alvinellidae, Vestimentifera) provide new mitochondrial COI clock calibration. Cahiers de Biologie Marine, 43, 367-370.

Clarke, K.R. \& Warwick, R.M. (2001) Change in marine communities: an approach to statistical analysis and interpretation, 2nd edn PRIMER-E Ltd, Plymouth, UK.

Colwell, R.K. \& Lees, D.C. (2000) The mid-domain effect: geometric constraints on the geography of species richness. Trends in Ecology and Evolution, 15, 70-76.

De'ath, G. (2002) Multivariate regression trees: A new technique for modeling speciesenvironment relationships. Ecology, 83, 1105-1117.

Desbruyères, D., Hashimoto, J. \& Fabri, M.-C. (2006a) Composition and biogeography of hydrothermal vent communities in western Pacific back-arc basins. Geophysical Monograph Series, 166, 215-234.

Desbruyères, D., Segonzac, M. \& Bright, M. (2006b) Handbook of deep-sea hydrothermal vent fauna, 2nd edn, Denisia 18, Linz, Austria.

Dreyer, J.C., Knick, K.E., Flickinger, W.B. \& Van Dover, C.L. (2005) Development of macrofaunal community structure in mussel beds on the northern East Pacific Rise. Marine Ecology Progress Series, 302, 121-134.

Dunn, R.R., Colwell, R.K. \& Nilsson, C. (2006) The river domain: why are there more species halfway up the river? Ecography, 29, 251-259.

Embley, R.W., Lupton, J.E., Massoth, G.J., Urabe, T., Tunnicliffe, V., Butterfield, D.A., Shibata, T., Okano, O., Kinioshita, M. \& Fujioka, K. (1998) Geological, chemical, and biological evidence for recent volcanism at $17.5^{\circ} \mathrm{S}$ : East Pacific Rise. Earth and Planetary Science Letters, 163, 131-147.

Folmer, O., Black, M.B., Hoeh, W.R., Lutz, R.A. \& Vrijenhoek, R.C. (1994) DNA primers for the amplification of mitochondrial cytochrome $c$ oxidase subunit I from diverse metazoan invertebrates. Molecular Marine Biology and Biotechnology, 3, 294-299.

Fornari, D.J. \& Embley, R.W. (1995) Tectonic and volcanic controls on hydrothermal processes at the mid-ocean ridge: an overview based on near-bottom and submersible studies. Seafloor hydrothermal systems (ed. by S.E. Humphris, R.A. Zierenberg, L.S. Mullineaux and R.E. Thomson). American Geophysical Union, Washington, DC.

Fouquet, Y., Auzende, J.-M., Ballu, V., Batiza, R., Bideau, D., Cormier, M.-H., Geistdoerfer, P., Lagabrielle, Y., Sinton, J. \& Spadea, P. (1994) Variabilité des manifestations hydrothermales actuelles le long d'une dorsale ultra-rapide: Exemple de la dorsale est Pacifique entre $17^{\circ} \mathrm{S}$ et $19^{\circ} \mathrm{S}$ (campagne Naudur). Comptes Rendus de l'Académie des Sciences, série II, 319, 1399-1406.

Fujioka, K., Massoth, G.J., de Ronde, C., Tanaka-Nakano, A., Gendron, J., Kinoshita, M., Nishizawa, A., Okano, O., Paradis, G., Roe, K.J., Shinohara, M., Shitashima, K., Tsunogai, U. \& Ytow, N. (1995) Active hydrothermal systems of a super-fast spreading ridge, southern East Pacific Rise (1358' S to $18^{\circ} 26^{\prime}$ S). InterRidge News, 4, 7-10.

Geistdoerfer, P., Auzende, J.-M., Batiza, R., Bideau, D., Cormier, M.-H., Fouquet, Y., Lagabrielle, Y., Sinton, J. \& Spadea, P. (1995) Hydrothermalisme et communautés animales associées sur la dorsale du Pacifique oriental entre $17^{\circ} \mathrm{S}$ et $19^{\circ} \mathrm{S}$ (campagne Naudur, décembre 1993). Comptes Rendus de l'Académie des Sciences, Série II, 320, 47-54. 
Govenar, B.W., Le Bris, N., Gollner, S., Glanville, J., Aperghis, A.B., Hourdez, S. \& Fisher, C.R. (2005) Epifaunal community structure associated with Riftia pachytila aggregations in chemically different hydrothermal vent habitats. Marine Ecology Progress Series, 305, 67-77. Halanych, K.M., Tieger, M., O'Mullan, G.D., Lutz, R.A. \& Vrijenhoek, R.C. (1999) Brief description of biological communities at $7^{\circ} \mathrm{S}$ on the East Pacific Rise. International RidgeCrest Research: Biological Studies, 8, 23-27.

Hall, T.A. (1999) BioEdit: a user-friendly biological sequence alignment editor and analysis program for Windows 95/98/NT. Nucleic Acids Symposium Series, 41, 95-98.

Hurlbert, S.H (1971) The nonconcept of species diversity: a critique and alternative parameters. Ecology, 52, 577-586.

Hurtado, L.A., Mateos, M., Lutz, R.A. \& Vrijenhoek, R.C. (2002) Molecular evidence for multiple species of Oasisia (Annelida: Siboglinidae) at eastern Pacific hydrothermal vents. Cahiers de Biologie Marine, 43, 377-380.

Hurtado, L.A., Lutz, R.A. \& Vrijenhoek, R.C. (2004) Distinct patterns of genetic differentiation among annelids of eastern Pacific hydrothermal vents. Molecular Ecology, 13, 2603-2615.

Johnson, S.B., Warén, A. \& Vrijenhoek, R.C. (2008) DNA barcoding of Lepetodrilus limpets reveals cryptic species. Journal of Shellfish Research, 27, 43-51.

Jollivet, D. (1996) Specific and genetic diversity at deep-sea hydrothermal vents: An overview. Biodiversity and Conservation, 5, 1619-1653.

Jollivet, D., Chevaldonné, P. \& Planque, B. (1999) Hydrothermal vent alvinellid polychaete dispersal in the eastern Pacific. 2. A metapopulation model based on habitat shifts. Evolution, 53, 1128-1142.

Jollivet, D., Lallier, F.H., Barnay, A.-S., Bienvenue, N., Bonnivard, E., Briand, P., CambonBonavita, M.-A., Comtet, T., Cosson, R., Daguin, C., Donval, J.-P., Faure, B., Gaillard, M., Glippa, V., Guillou, L., Hourdez, S., Le Bris, N., Morand, S., Pradillon, F., Rees, J.-F., Segonzac, M., Shillito, B., Thiébaut, E. \& Viard, F. (2005) The Biospeedo cruise: A new survey of hydrothermal vents along the south East Pacific Rise from $7^{\circ} 24^{\prime} S$ to $21^{\circ} 33^{\prime} \mathrm{S}$. InterRidge News, 13, 20-26.

Juniper, S.K. \& Tunnicliffe, V. (1997) Crustal accretion and the hot vent ecosystem. Philosophical Transactions of the Royal Society A: Mathematical, physical \& Engineering Sciences, 355, 459-474.

Kimura, M. (1980) A simple method for estimating evolutionary rates of base substitutions through comparative studies of nucleotide sequences. Journal of Molecular Evolution, 15, 111-120.

Knowlton, N. (1993) Sibling species in the sea. Annual Review of Ecology and Systematics, 24, 189-216.

Knowlton, N. (2000) Molecular genetic analyses of species boundaries in the sea. Hydrobiologia, 420, 73-90.

Legendre, P. \& Gallagher, E. (2001) Ecologically meaningful transformations for ordination of species data. Oecologia, 129, 271-280.

Legendre, P. \& Legendre, L. (1998) Numerical ecology, $2^{\text {nd }}$ edn, Elsevier, Amsterdam.

Little, C.T.S. \& Vrijenhoek, R.C. (2003) Are hydrothermal vent animals living fossils? Trends in Ecology and Evolution, 18, 582-588.

Lonsdale, P. (1977) Clustering of suspension-feeding macrobenthos near abyssal hydrothermal vents at oceanic spreading centers. Deep-Sea Research, 24, 857-863.

Matabos, M., Thiébaut, E., Le Guen, D., Sadosky, F., Jollivet, D. \& Bonhomme, F. (2008a) Geographic clines and stepping-stone patterns detected along the East Pacific Rise in the vetigastropod Lepetodrilus elevatus reflect species crypticism. Marine Biology, 153, 545-563. Matabos, M., Le Bris, N., Pendlebury, S. \& Thiébaut, E. (2008b) Role of physico-chemical environment on gastropod assemblages at hydrothermal vents on the East Pacific Rise $\left(13^{\circ}\right.$ N/EPR). Journal of the Marine Biological Association of the United Kingdom, 88, 995-1008.

Micheli , F., Peterson, C.H., Mullineaux, L.S., Fisher, C.R., Mills, S.W., Sancho, G., Johnson, G.A. \& Lenihan, H.S. (2002) Predation structures communties at deep-sea hydrothermal vents. Ecological Monographs, 72, 365-382. 
Mills, S.W., Mullineaux, L.S. \& Tyler, P.A. (2007) Habitat associations in gastropod species at East Pacific Rise hydrothermal vents (950' N). Biological Bulletin, 212, 185-194.

Monge-Najera, J. (2008) Ecological biogeography: a review with emphasis on conservation and the neutral model. Gayana, 72, 102-112.

Mullineaux, L.S., Peterson, C.H., Micheli, F. \& Mills, S.W. (2003) Successional mechanism varies along a gradient in hydrothermal fluid flux at deep-sea vents. Ecological Monographs, 73, 523-542.

Nelson, K. \& Fisher, C.R. (2000) Absence of cospeciation in deep-sea vestimentiferan tube worms and their bacterial endosymbionts. Symbiosis, 28, 1-15.

Palumbi, S.R. (1996) What can molecular genetics contribute to marine biogeography? Journal of Experimental Marine Biology and Ecology, 203, 75-92.

Peek, A.S., Gustafson, R.G., Lutz, R.A. \& Vrijenhoek, R.C. (1997) Evolutionary relationships of deep-sea hydrothermal vent and cold-water seep clams (Bivalvia: Vesicomyidae): results from the mitochondrial cytochrome oxidase subunit I. Marine Biology, 130, 151-161.

Plouviez, S., Shank, T.M., Faure, B., Daguin-Thiébaut, C., Viard, F., Lallier, F.H. \& Jollivet D. (2009) Comparative phylogeography among hydrothermal vent species along the East Pacific Rise reveals vicariant processes and population expansion in the south. Molecular Ecology, 18, 3903-3917.

Posada, D. \& Crandall, K.A. (1998) MODELTEST: testing the model of DNA substitution. Bioinformatics Applications Note, 14, 817-818.

R Development Core Team (2006) R: a language and environment for statistical computing. R Foundation for Statistical Computing, Vienna, Austria.

Ronquist, F. \& Huelsenbeck, J.P. (2003) Mr Bayes 3: Bayesian phylogenetic inference under mixed models. Bioinformatics, 19, 1572-1574.

Sarrazin, J., Robigou, V., Juniper, S.K. \& Delaney, J.R. (1997) Biological and geological dynamics over four years on a high-temperature sulfide structure at the Juan de Fuca ridge hydrothermal observatory. Marine Ecology Progress Series, 153, 5-24.

Shank, T.M., Fornari, D.J., Von Damm, K.L., Lilley, M.D., Haymon, R.M. \& Lutz, R.A. (1998) Temporal and spatial patterns of biological community development at nascent deep-sea hydrothermal vents (950' N, East Pacific Rise). Deep-Sea Research II, 45, 465-515.

Spalding, M.D., Fox, H.E., Allen, G.R., Davidson, N., Ferdaña, Z.A., Finlayson, M., Halpern, B.S., Jorge, M.A., Lombana, A., Lourie, S.A., Martin, K.D., McManus, E., Molnar, J., Recchia, C.A. \& Robertson, J. (2007) Marine ecoregions of the world: a bioregionalization of coastal and shelf areas. BioScience, 57, 573-583.

Stöhr, S. \& Segonzac, M. (2006) Two new genera and species of ophiuroid (Echinodermata) from hydrothermal vents in the East Pacific. Species Diversity, 11, 7-32.

Tunnicliffe, V. (1988) Biogeography and evolution of hydrothermal-vent fauna in the Eastern Pacific ocean. Proceedings of the Royal Society B: Biological Sciences, 233, 347-366.

Tunnicliffe, V. (1991) The biology of hydrothermal vents: Ecology and evolution. Oceanography and Marine Biology: an Annual Review, 29, 319-407.

Tunnicliffe, V. \& Fowler, C.M.R. (1996) Influence of sea-floor spreading on the global hydrothermal vent fauna. Nature, 379, 531-533.

Tunnicliffe, V., McArthur, A.G. \& McHugh, D. (1998) A biogeographical perspective of the deep-sea hydrothermal vent fauna. Advances in Marine Biology, 34, 353-442.

Turnipseed, M., Knick, K.E., Lipcius, R.N., Dreyer, J.C. \& Van Dover, C.L. (2003) Diversity in mussel beds at deep-sea hydrothermal vents and cold seep. Ecology Letters, 6, 518-523.

Tyler, P.A., German, C.R., Ramirez-Llodra, E. \& Van Dover, C.L. (2003) Understanding the biogeography of chemosynthetic ecosystems. Oceanologica Acta, 25, 227-241.

Van Dover, C.L. (2000) The ecology of deep-sea hydrothermal vents. Princeton University Press, Princeton, NJ.

Van Dover, C.L. (2002) Community structure of mussels beds at deep-sea hydrothermal vents. Marine Ecology Progress Series, 230, 137-158.

Van Dover, C.L. (2003) Variation in community structure within hydrothermal vent mussel beds of the East Pacific Rise. Marine Ecology Progress Series, 253, 55-66. 
Van Dover, C.L. \& Doerries, M.B. (2005) Community structure in mussel beds at Logatchev hydrothermal vents and a comparison of macrofaunal species richness on slow- and fastspreading mid-ocean ridges. Marine Ecology, 26, 110-120.

Van Dover, C.L, Homphris, S.E., Fornari, D.J., Cavanaugh, C.M., Collier, R., Goffredi, S.K., Hashimoto, J., Lilley, M.D., Reysenbach, A.L., Shank, T.M., Von Damm, K., Banta, A., Gallant, R.M. \& Vrijenhoek, R.C. (2001) Biogeography and ecological setting of Indian ocean hydrothermal vents. Science, 294, 818-823.

Van Dover, C.L, German, C.R., Speer, K.G., Parson, L.M. \& Vrijenhoek, R.C. (2002) Evolution and biogeography of deep-sea vent and seep invertebrates. Science, 295, 12531257.

Via, S. (2001) Sympatric speciation in animals: the ugly duckling grows up. Trends in Ecology and Evolution, 16, 381-390.

Vrijenhoek, R.C. (2009) Cryptic species, phenotypic plasticity, and complex life histories: assessing deep-sea faunal diversity with molecular markers. Deep-Sea Research II, 56, 1713-1723.

Warén, A. \& Bouchet, P. (2001) Gastropoda and Monoplacophora from hydrothermal vents and seeps: new taxa and records. Veliger, 44, 116-231.

Warwick, R.M. \& Clarke, K.R. (1995) New 'biodiversity' measures reveal a decrease in taxonomic distinctness with increasing stress. Marine Ecology Progress Series, 129, 301305.

Warwick, R.M. \& Clarke, K.R. (2001) Practical measures of marine biodiversity based on relatedness of species. Oceanography and Marine Biology: an Annual Review, 39, 207-231.

Won, Y., Young, C.R., Lutz, R.A. \& Vrijenhoek, R.C. (2003) Dispersal barriers and isolation among deep-sea mussel populations (Mytilidae: Bathymodiololus) from eastern Pacific hydrothermal vents. Molecular Ecology, 12, 169-184.

Young, C.R., Fujio, S. \& Vrijenhoek, R.C. (2008) Directional dispersal between mid-ocean ridges: deep-ocean circulation and gene flow in Ridgeia piscesae. Molecular Ecology, 17, 1718-1731. 


\section{Supporting information}

Additional Supporting Information may be found in the online version of this article:

Appendix S1 Species list of macrobenthic invertebrates along the East Pacific Rise (EPR).

As a service to our authors and readers, this journal provides supporting information supplied by the authors. Such materials are peer-reviewed and may be re-organized for online delivery, but are not copy-edited or typeset. Technical support issues arising from supporting information (other than missing files) should be addressed to the authors.

\section{Biosketch}

Marjolaine Matabos is a post-doctoral fellow at the School of Earth and Ocean Sciences, University of Victoria. Her research there consists of developing new methods, using undersea imagery, to understand ecological processes occurring on the seafloor. She completed her PhD thesis at "Université Pierre et Marie Curie" in Paris, France. Using several disciplinary approaches, her previous research sought to understand biodiversity patterns associated with hydrothermal vents, and how factors are able to shape them in time and space.

Author contributions: M.M., D.J. and E.T. conceived the ideas; M.M. and S.P. collected the molecular data; M.M., A.W., S.H., E.T. and D.D. collected data and/or provided morphological identification; M.M. and P.L. analysed the data; and M.M. and D.J. led the writing

Editor: John Lambshead 


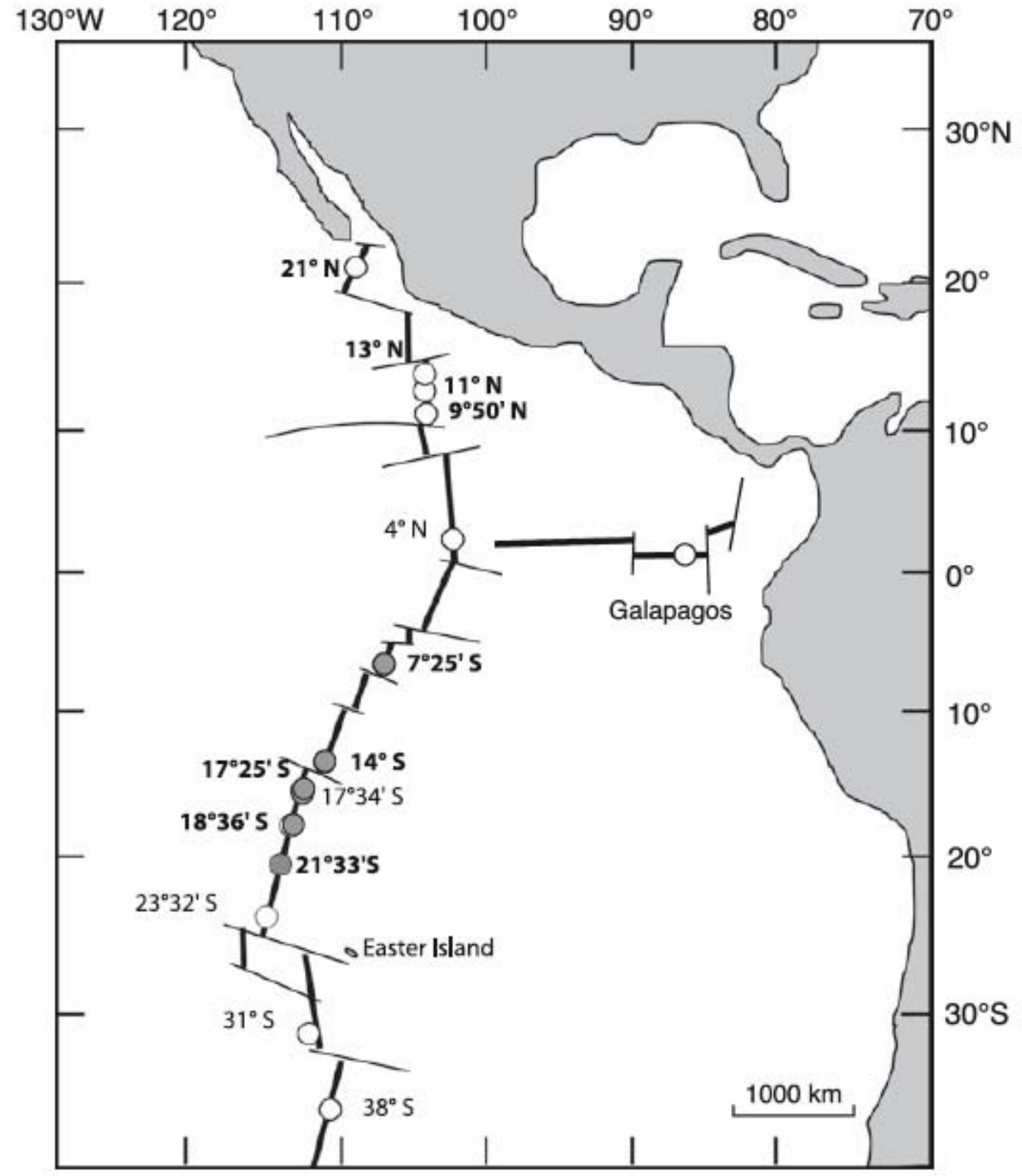

Figure 1 Locations of the hydrothermal vent fields along the East Pacific Rise. Vent fields visited during the BIOSPEEDO cruise along the southern East Pacific Rise are represented in grey. Vent fields included in the global analysis of the macrobenthic invertebrate species list are indicated in bold. 


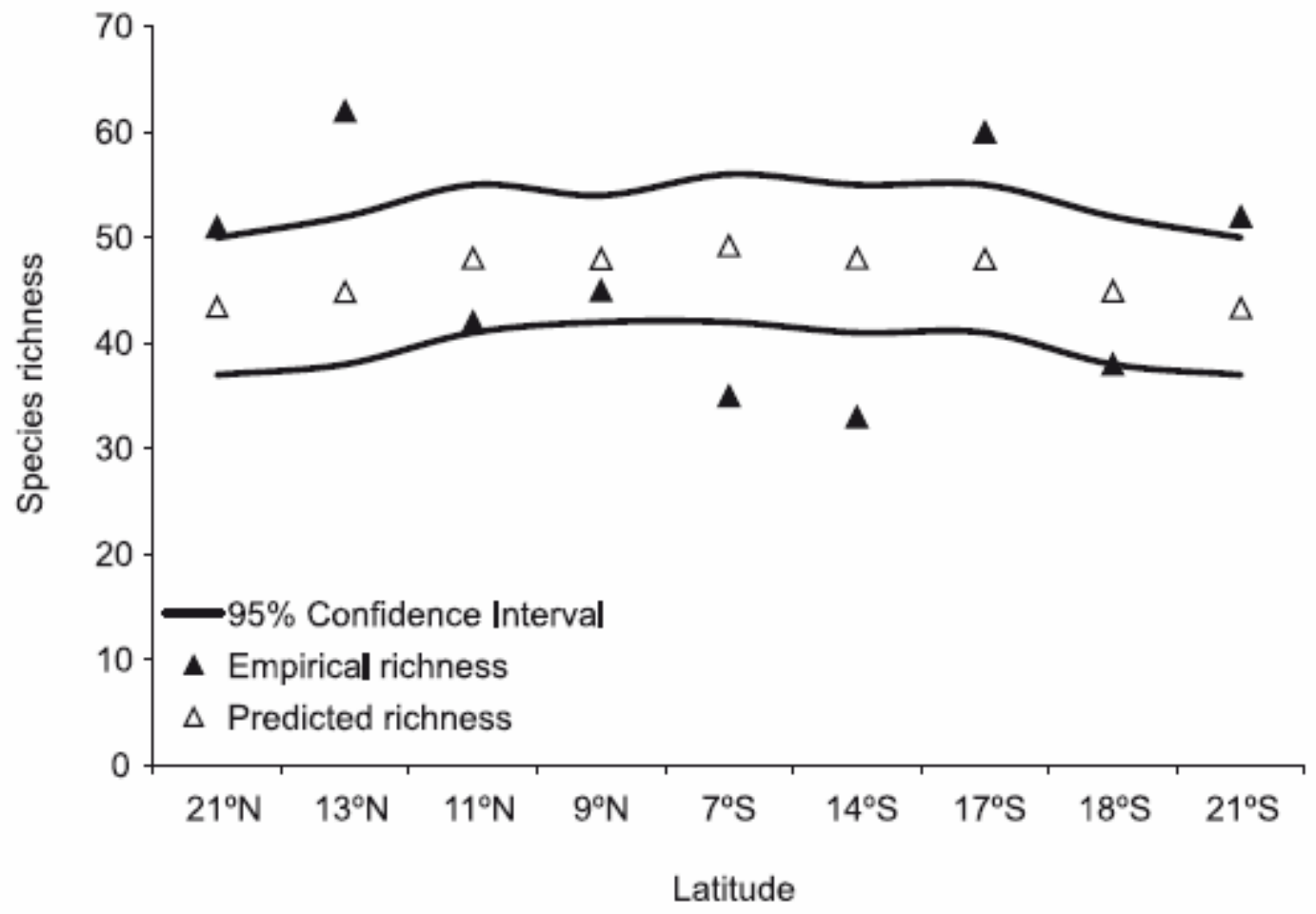

Figure 2 Empirical (black triangles) and predicted (open triangles) species richness of macrobenthic invertebrate communities along the East Pacific Rise. The 95\% confidence intervals, indicated by the lines, are based on 9999 randomizations of range placement for the set of empirical range sizes, taking distributional gaps into account. 


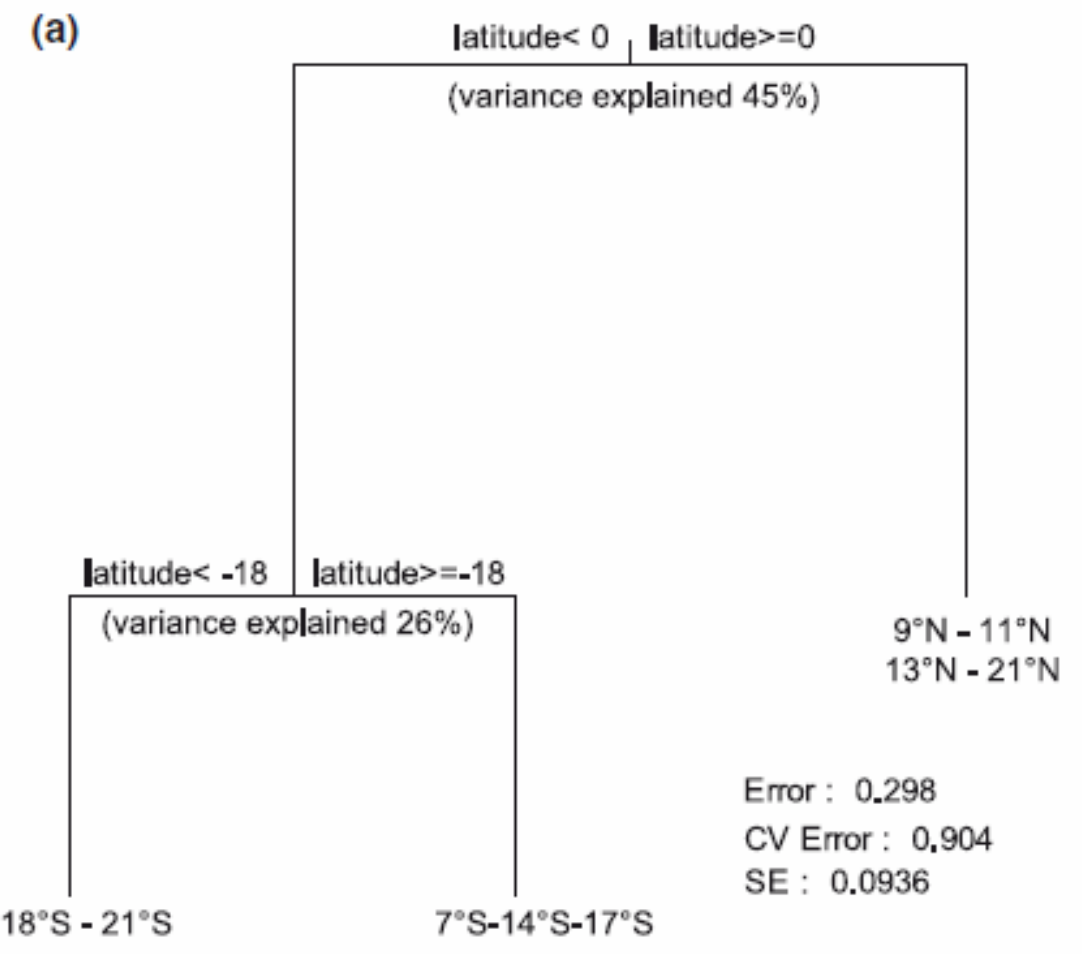

(b) latitude $<0$ | latitude $>=0$

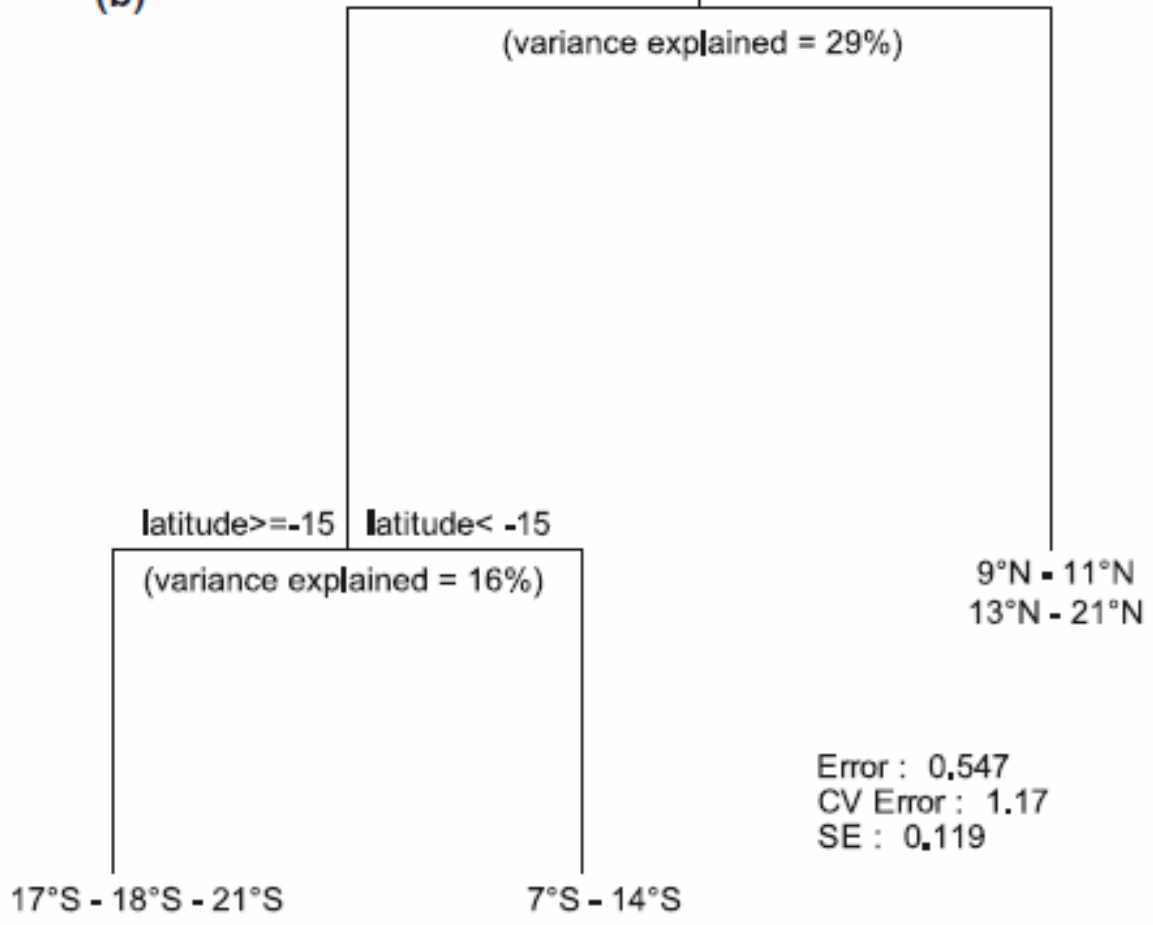

Figure 3 Groups obtained by multivariate regression tree analysis of presence-absence data along the East Pacific Rise. Negative latitudes shown on the splits are south of the equator. (a) Data from the Handbook of deep-sea hydrothermal vent fauna (Desbruye' res et al., 2006b). (b) Species list complemented with data from the BIOSPEEDO cruise. 


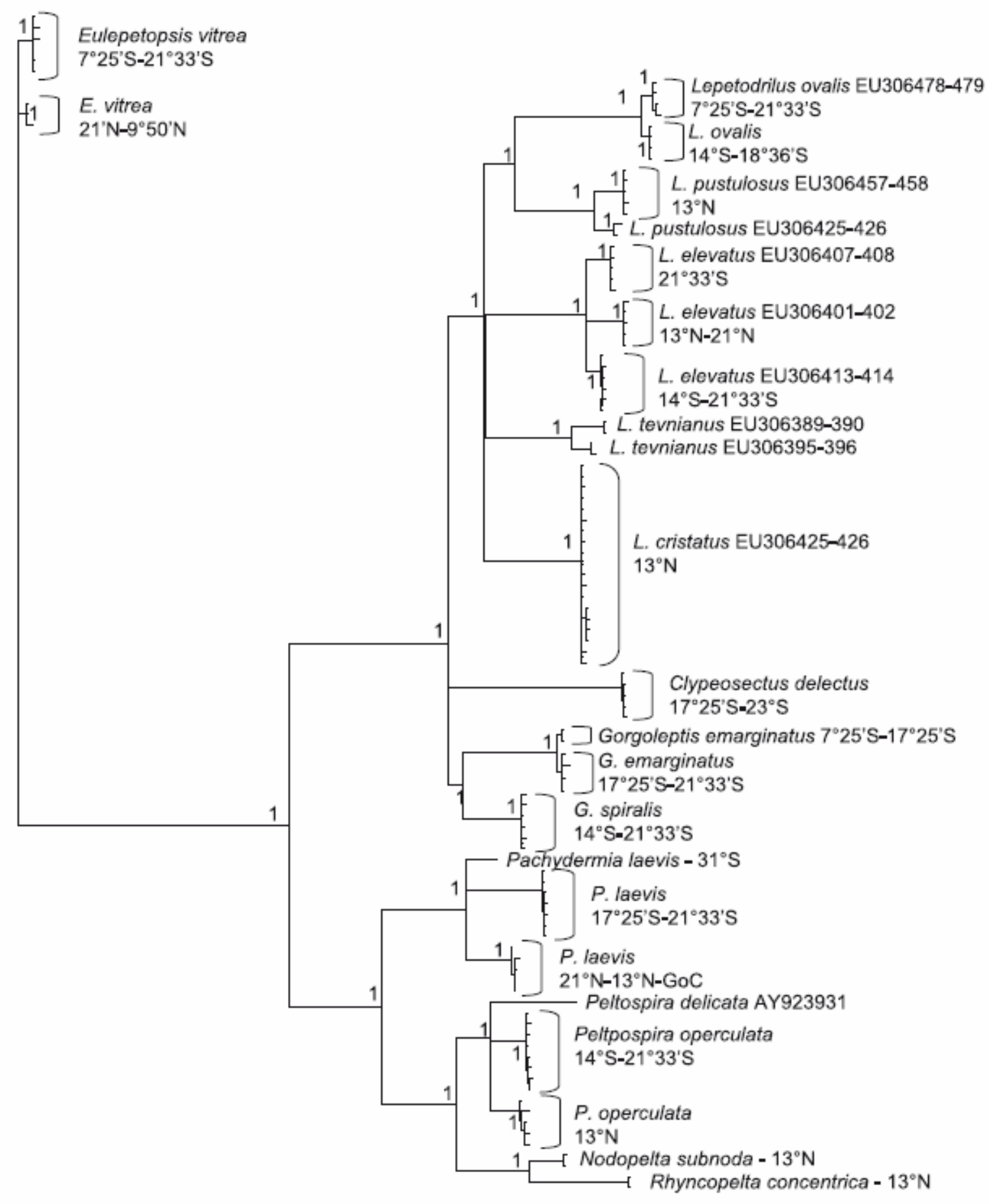

$\underline{0.1}$

Figure 4 Phylogenetic relationships among 14 species of gastropods along the East Pacific Rise (COI sequences of 111 individuals) computed by Bayesian inferences. Numbers along the tree correspond to the posterior probability values of the nodes. GenBank sequences added to the tree were provided by Johnson et al. (2008). Site abbreviations are as in Table 1. 


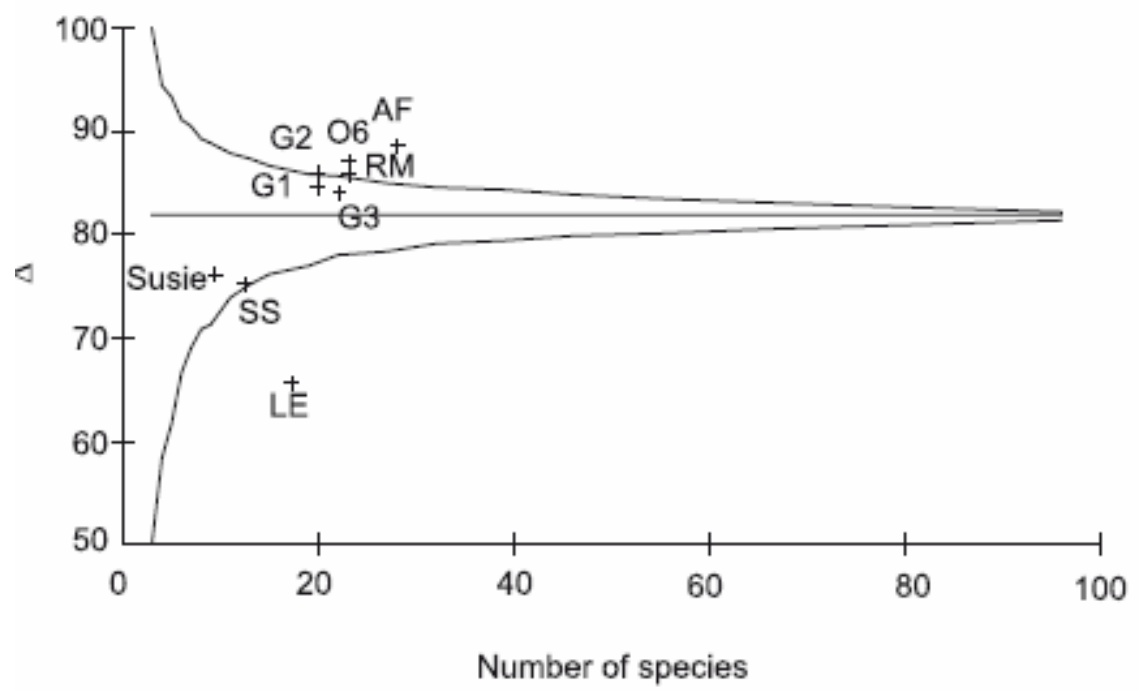

Figure 5 Computed values of average taxonomic distinctness ( $\left.\mathrm{D}_{+}\right)$from the semi-quantitative sampling units collected in the mussel beds along the southern East Pacific Rise, plotted against the number of species on the simulated 95\% confidence interval generated after 1000 re-samplings of the same number of species from the total southern East Pacific Rise species list. Site abbreviations are as in Table 1.

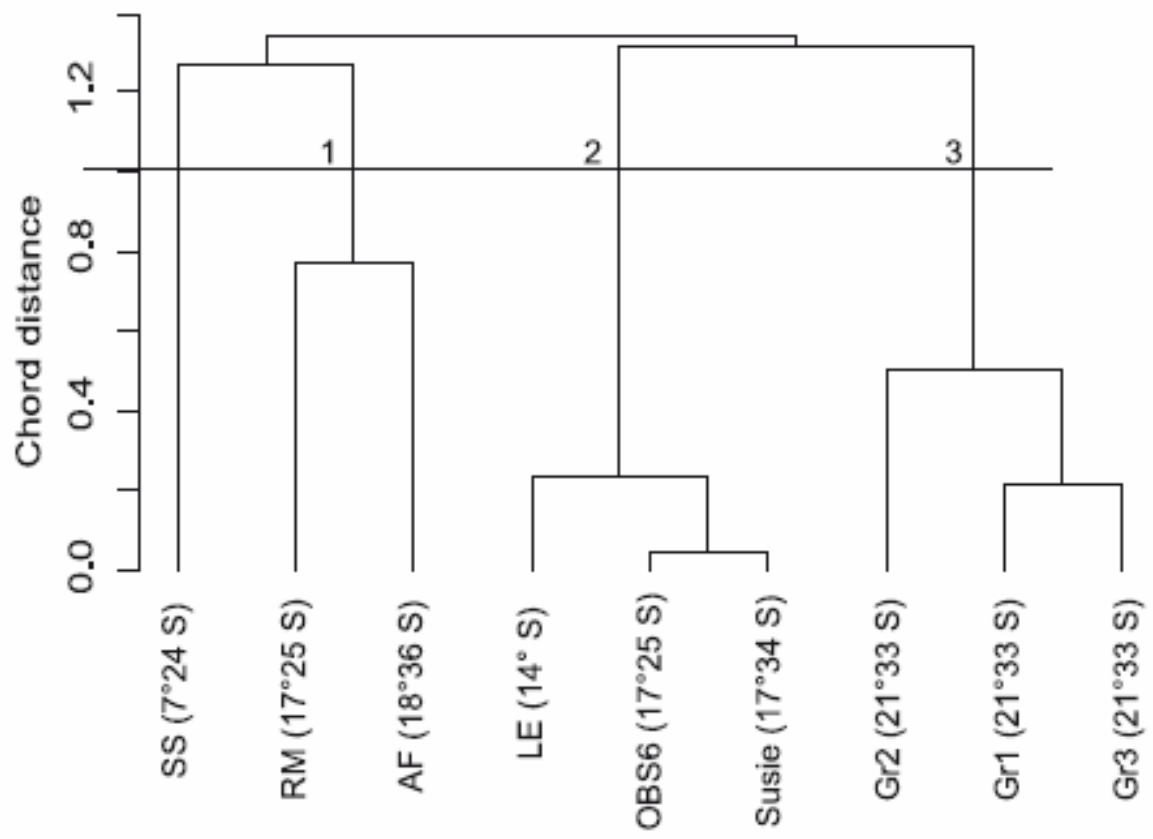

Figure 6 Group-average sorting (UPGMA unweighted pairgroup method using arithmetic averages) dendrogram computed from the chord distance among the nine sampling units collected in mussel beds along the southern East Pacific Rise. Numbers identify clusters. Site abbreviations are as in Table 1. 


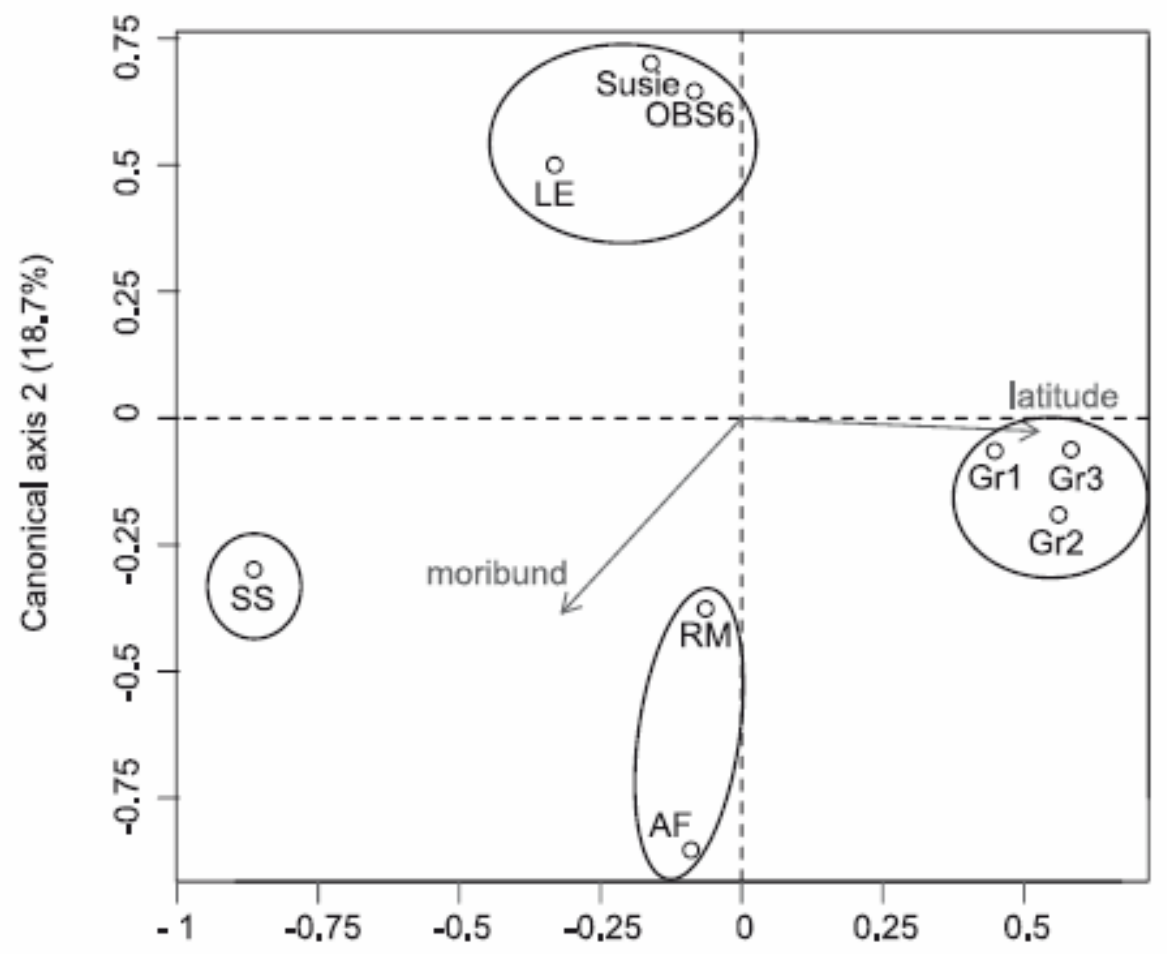

Canonical axis $1(27.6 \%)$

Figure 7 Redundancy analysis ordination correlation biplot of the sites and environmental variables based on the transformed species abundance of macrobenthic invertebrate communities associated with mussel beds along the southern East Pacific Rise. Site abbreviations are as in Table 1. Groups identified in the dendrogram (Fig. 6) are represented with ellipses. Environmental variables: latitude and type of venting (i.e. moribund). Species are not represented. 
Table 1 Characteristics of the localities and sampling units for each Bathymodiolus thermophilus mussel bed sampled along the southern East Pacific Rise (SEPR). Macrofaunal density corresponds to the number of individuals standardized to the estimated surface area sampled.

\begin{tabular}{|c|c|c|c|c|c|c|c|c|c|c|c|}
\hline Vent field & Vent sites & Latitude & Longitude & Dive & $\begin{array}{l}\text { Geodynamic } \\
\text { environment }\end{array}$ & $\begin{array}{l}\text { Type of } \\
\text { venting }\end{array}$ & $\begin{array}{l}\text { No. of } \\
\text { mussels }\end{array}$ & $\begin{array}{l}\text { Size range } \\
(\mathrm{mm})\end{array}$ & $\begin{array}{l}\text { Proportion of } \\
\text { juveniles (\%) }\end{array}$ & $\begin{array}{l}\text { Sampled } \\
\text { area }\left(\mathrm{cm}^{2}\right)\end{array}$ & $\begin{array}{l}\text { Density of } \\
\text { individuals } \\
\text { (ind. } \mathrm{m}^{-2} \text { ) }\end{array}$ \\
\hline $7^{\circ} 25^{\prime} \mathrm{S}$ & Sarah's Spring (SS) & $7^{\circ} 25.2445^{\prime} \mathrm{S}$ & $107^{\circ} 47.6386^{\prime} \mathrm{W}$ & 1574 & Volcanic & Moribund & 46 & $0-80$ & 9 & 687 & 3959 \\
\hline $13^{\circ} 59^{\prime} \mathrm{S}$ & Ludky Eric (LE) & $13^{\circ} 59.2093^{\prime} \mathrm{S}$ & $112^{\circ} 28.9559^{\prime} \mathrm{W}$ & 1592 & Tectonic & Diffusion & 84 & $0-170$ & 39 & 3581 & 1170 \\
\hline \multirow[t]{2}{*}{$17^{\circ} 25^{\prime} \mathrm{S}$} & Oasis BS6 (OBS6) & $17^{\circ} 25.3843^{\prime} \mathrm{S}$ & $113^{\circ} 12.2893^{\prime} \mathrm{W}$ & 1579 & Volcanic & Diffusion & 147 & $0-170$ & 3 & 8438 & 2028 \\
\hline & Rehu Marka (RM) & $17^{\circ} 24.9787^{\prime} \mathrm{S}$ & $113^{\circ} 12.1369^{\prime} \mathrm{W}$ & 1590 & Volcanic & Diffusion & 91 & $0-160$ & 2 & 11081 & 771 \\
\hline $17^{0} 34^{\prime} \mathrm{S}$ & Susie (Susie) & $17^{\circ} 35.4718^{\prime} \mathrm{S}$ & $113^{\circ} 14.8252^{\prime} \mathrm{W}$ & 1588 & Tectonic & Chimney & 607 & $0-170$ & 69 & 9888 & 1794 \\
\hline $18^{\circ} 36^{\prime} \mathrm{S}$ & Animal Farm (AF) & $18^{\circ} 36.6966^{\prime} \mathrm{S}$ & $113^{\circ} 24.0482^{\prime} \mathrm{W}$ & 1585 & Volcanic & Moribund & 379 & $0-130$ & 56 & 8735 & 2249 \\
\hline \multirow[t]{3}{*}{$21^{\circ} 33^{\prime} \mathrm{S}$} & Grommit (Grl) & $21^{\circ} 33.6695^{\prime} \mathrm{S}$ & $114^{\circ} 17.9049^{\prime} \mathrm{W}$ & 1575 & Tectonic & Chimney & 238 & $10-120$ & 0 & 15326 & 647 \\
\hline & Grommit (Gr2) & $21^{\circ} 33.6648^{\prime} \mathrm{S}$ & $114^{\circ} 17.9814^{\prime} \mathrm{W}$ & 1577 & Tectonic & Chimney & 76 & $20-120$ & 0 & 4823 & 832 \\
\hline & Grommit (Gr3) & $21^{\circ} 33.6848^{\prime} \mathrm{S}$ & $114^{\circ} 17.9808^{\prime} \mathrm{W}$ & 1578 & Tectonic & Chimney & 430 & $0-120$ & 9 & 11353 & 845 \\
\hline
\end{tabular}


Table 2 List of gastropod species from the East Pacific Rise (EPR) used in the barcoding analysis. The number of specimens per locality is given in parentheses.

\begin{tabular}{|c|c|c|}
\hline Species & This study & GenBank accession numbers \\
\hline Eulepetopsis vitrea & $\begin{array}{l}21^{\circ} \mathrm{N}(1), 13^{\circ} \mathrm{N}(1), 9^{\circ} 50^{\prime} \mathrm{N}(1), 7^{\circ} 25^{\prime} \mathrm{S}(1), 13^{\circ} 59^{\prime} \mathrm{S}(1), \\
17^{\circ} 25^{\prime} \mathrm{S}(1), 17^{\circ} 34^{\prime} \mathrm{S}(1), 18^{\circ} 36^{\prime} \mathrm{S}(1), 21^{\circ} 33^{\prime} \mathrm{S}(1)\end{array}$ & \\
\hline Lepetodrilus elevatus & $\begin{array}{l}21^{\circ} \mathrm{N}(1), 13^{\circ} \mathrm{N}(2), 13^{\circ} 59^{\prime} \mathrm{S}(1), 17^{\circ} 25^{\prime} \mathrm{S}(1) \\
17^{\circ} 34^{\prime} \mathrm{S}(1), 21^{\circ} 33^{\prime} \mathrm{S}(4)\end{array}$ & EU306401-402 (Wood: $22^{\circ} \mathrm{N} / \mathrm{EPR}: 21^{\circ} \mathrm{N}-0^{\circ}$ ) \\
\hline Lepetodrilus aff. elevatus & & EU306407-408 (EPR:7 $\left.{ }^{\circ} \mathrm{S}-38^{\circ} \mathrm{S}\right)$ \\
\hline Lepetodrilus aff. galriftensis & & EU306413-414 (EPR:9 N-23ㅇ S) \\
\hline Lepetodrilus ovalis & $\begin{array}{l}7^{\circ} 25^{\prime} \mathrm{S}(1), 13^{\circ} 59^{\prime} \mathrm{S}(1), 17^{\circ} 25^{\prime} \mathrm{S}(1), 17^{\circ} 34^{\prime} \mathrm{S}(1), \\
18^{\circ} 36^{\prime} \mathrm{S}(1), 21^{\circ} 33^{\prime} \mathrm{S}(1)\end{array}$ & EU306478-479 (EPR:Monterey Bay/EPR:21 ${ }^{\circ} \mathrm{N}-38^{\circ} \mathrm{S}$ ) \\
\hline Lepetodrilus pustulosus & $13^{\circ} \mathrm{N}(3)$ & EU306457-458 (Wood: $22^{\circ} \mathrm{N} / \mathrm{EPR}: 21^{\circ} \mathrm{N}-17^{\circ} \mathrm{S}$ ) \\
\hline Lepetodrilus aff. pustulosus & & EU306464-465 (EPR:31 $\left.1^{\circ} \mathrm{S}-38^{\circ} \mathrm{S}\right)$ \\
\hline Lepetodrilus tevnianus & & EU306389-390 (EPR:9 N-23ㅇ S) \\
\hline Lepetodrilus aff. tevnianus & & EU306395-396 (EPR:23은 $\left.\mathrm{S}-31^{\circ} \mathrm{S}\right)$ \\
\hline Lepetodrilus cristatus & $13^{\circ} \mathrm{N}(17)$ & EU306425-426 (EPR:21 $\left.{ }^{\circ} \mathrm{N}-38^{\circ} \mathrm{S}\right)$ \\
\hline Gorgoleptis emarginatus & $7^{\circ} 25^{\prime} \mathrm{S}(2), 13^{\circ} 59^{\prime} \mathrm{S}(1), 17^{\circ} 25^{\prime} \mathrm{S}(2), 21^{\circ} 33^{\prime} \mathrm{S}(1)$ & \\
\hline Gorgoleptis spiralis & $14^{\circ} \mathrm{S}(1), 17^{\circ} 24^{\prime} \mathrm{S}(2), 21^{\circ} 33^{\prime} \mathrm{S}(3)$ & \\
\hline Clypeosectus delectus & $17^{\circ} 25^{\prime} \mathrm{S}(2), 21^{\circ} 33^{\prime} \mathrm{S}(1), 23^{\circ} \mathrm{S}(2)$ & \\
\hline Pachydermia laevis & $\begin{array}{l}21^{\circ} \mathrm{N}(3), \mathrm{GoC}(1), 13^{\circ} \mathrm{N}(1), 17^{\circ} 25^{\prime} \mathrm{S}(2), 17^{\circ} 34^{\prime} \mathrm{S}(1) \\
18^{\circ} 36^{\prime} \mathrm{S}(2), 21^{\circ} 33^{\prime} \mathrm{S}(2), 31^{\circ} \mathrm{S}(1)\end{array}$ & \\
\hline Peltospira operculata & $\begin{array}{l}13^{\circ} \mathrm{N}(4), 13^{\circ} 59^{\prime} \mathrm{S}(2), 17^{\circ} 25^{\prime} \mathrm{S}(1), 17^{\circ} 34^{\prime} \mathrm{S}(1) \\
18^{\circ} 36^{\prime} \mathrm{S}(2), 21^{\circ} 33^{\prime} \mathrm{S}(2)\end{array}$ & \\
\hline Peltospira delicata & & AY923931 \\
\hline Nodopelta subnoda & $13^{\circ} \mathrm{N}(2)$ & \\
\hline Rhynchopelta concentrica & $13^{\circ} \mathrm{N}(2)$ & \\
\hline
\end{tabular}


Table 3. Diversity indices for each hydrothermal vent field along the East Pacific Rise (EPR), computed from presence-absence data of macrobenthic invertebrate species. EPR handbook, data reported in the Handbook of deep-sea hydrothermal vent fauna (Desbruye 'res et al., 2006b); EPR hb+bs, species collected along the southern EPR during the BIOSPEEDO cruise (bs) were added to the handbook data (hb). S, species richness; D+, average taxonomic distinctness.

\begin{tabular}{|c|c|c|c|c|}
\hline \multirow[b]{2}{*}{ Vent site } & \multicolumn{2}{|c|}{ EPR handbook } & \multicolumn{2}{|c|}{ EPR hb+bs } \\
\hline & $S$ & $\Delta^{+}$ & $S$ & $\Delta^{+}$ \\
\hline $21^{\circ} \mathrm{N}$ & 51 & 79.79 & 51 & 79.79 \\
\hline $13^{\circ} \mathrm{N}$ & 62 & 80.94 & 62 & 80.94 \\
\hline $11^{\circ} \mathrm{N}$ & 42 & 80.22 & 42 & 80.22 \\
\hline $9^{\circ} 50^{\prime} \mathrm{N}$ & 45 & 79.41 & 45 & 79.41 \\
\hline $7^{\circ} 25^{\prime} \mathrm{S}$ & 21 & 78.73 & 35 & 79.33 \\
\hline $13^{\circ} 59^{\prime} \mathrm{S}$ & 22 & 79.73 & 34 & 79.32 \\
\hline $17^{\circ} 25^{\prime}-34^{\prime} \mathrm{S}$ & 28 & 84.48 & 60 & 81.96 \\
\hline $18^{\circ} 36^{\prime} \mathrm{S}$ & 14 & 79.3 & 38 & 83.95 \\
\hline $21^{\circ} 33^{\prime} \mathrm{S}$ & 13 & 76.5 & 52 & 80.62 \\
\hline
\end{tabular}


Table 4 List of macrobenthic invertebrate species of the communities associated with nine Bathymodiolus thermophilus mussel beds sampled along the southern East Pacific Rise (SEPR).

\begin{tabular}{|c|c|c|c|c|c|c|c|c|c|c|c|}
\hline Taxon & Family & Species & $\begin{array}{l}\text { Sarah's Spring } \\
\left(7^{\circ} 25^{\prime} S\right)\end{array}$ & $\begin{array}{l}\text { Lucky Eric } \\
\left(13^{\circ} 59^{\prime} \mathrm{S}\right)\end{array}$ & $\begin{array}{l}\text { Oasis BS6 } \\
\left(17^{\circ} 25^{\prime} \mathrm{S}\right)\end{array}$ & $\begin{array}{l}\text { Rehu Marka } \\
\left(17^{\circ} 25^{\prime} \mathrm{S}\right)\end{array}$ & $\begin{array}{l}\text { Susie } \\
\left(17^{\circ} 34^{\prime} \mathrm{S}\right)\end{array}$ & $\begin{array}{l}\text { Animal Farm } \\
\left(18^{\circ} 36^{\prime} \mathrm{S}\right)\end{array}$ & $\begin{array}{l}\text { Grommit (1) } \\
\left(21^{\circ} 33^{\prime} \mathrm{S}\right)\end{array}$ & $\begin{array}{l}\text { Grommit (2) } \\
\left(21^{\circ} 33^{\prime} \mathrm{S}\right)\end{array}$ & $\begin{array}{l}\text { Grommit (3) } \\
\left(21^{\circ} 33^{\prime} \mathrm{S}\right)\end{array}$ \\
\hline \multirow[t]{28}{*}{ Gastropods } & Neolepetopsidae & Eulepetopsis vitrea & 291 & 170 & 20 & 76 & 41 & 449 & 10 & 6 & 21 \\
\hline & Trochidae & Bathymargarites simplector & 15 & 0 & 8 & 7 & 0 & 260 & 0 & 0 & 0 \\
\hline & Sutilizonidae & Sutilizona theca & 0 & 0 & 0 & 0 & 0 & 0 & 2 & 0 & 0 \\
\hline & \multirow[t]{9}{*}{ Lepetodrilidae } & Lepetodrilus elevatus & 15 & 757 & 1791 & 19 & 1607 & 2 & 42 & 29 & 102 \\
\hline & & Lepetodrilus pustulosus & 1877 & 64 & 0 & 0 & 6 & 0 & 0 & 0 & 2 \\
\hline & & Lepetodrilus ovalis & 87 & 103 & 63 & 219 & 114 & 218 & 11 & 12 & 57 \\
\hline & & Lepetodrilus cristatus & 0 & 25 & 0 & 0 & 2 & 0 & 5 & 10 & 4 \\
\hline & & Lepetodrilus tevnianus & 0 & 17 & 0 & 0 & 4 & 0 & 1 & 2 & 2 \\
\hline & & Gorgoleptis cf. emarginatus & 73 & 3 & 0 & 17 & 1 & 0 & 0 & 0 & 5 \\
\hline & & Gorgoleptis spiralis & 15 & 8 & 32 & 48 & 0 & 10 & 5 & 12 & 15 \\
\hline & & Gorgoleptis patulus & 0 & 0 & 1 & 0 & 0 & 0 & 0 & 0 & 0 \\
\hline & & Clypeosectus sp. & 58 & 0 & 14 & 23 & 0 & 0 & 0 & 2 & 0 \\
\hline & \multirow[t]{7}{*}{ Neomphalidae } & Cyathermia naticoides & 0 & 0 & 0 & 0 & 0 & 0 & 0 & 0 & 0 \\
\hline & & Melanodrymia auriantica & 0 & 0 & 0 & 0 & 0 & 0 & 472 & 309 & 458 \\
\hline & & Melanodrymia galeronae & 0 & 0 & 0 & 0 & 0 & 0 & 1 & 0 & 0 \\
\hline & & Melanodrymia n. sp. & 0 & 0 & 0 & 0 & 0 & 0 & 1 & 0 & 0 \\
\hline & & Pachydermia cf. laevis & 0 & 0 & 0 & 33 & 0 & 0 & 18 & 6 & 20 \\
\hline & & Planorbidella cf. planispira & 0 & 3 & 17 & 29 & 2 & 18 & 2 & 2 & 12 \\
\hline & & Neomphalus fretterae & 0 & 0 & 1 & 0 & 0 & 1 & 0 & 0 & 0 \\
\hline & \multirow[t]{3}{*}{ Peltospiridae } & Nodopelta subnoda & 0 & 0 & 0 & 0 & 0 & 0 & 0 & 15 & 0 \\
\hline & & Echinopelta fistulosa & 0 & 0 & 0 & 0 & 0 & 0 & 0 & 149 & 0 \\
\hline & & Rhynchopelta concentrica & 0 & 0 & 0 & 0 & 2 & 0 & 0 & 0 & 0 \\
\hline & Phenacolepapidae & Shinkailepas sp. & 0 & 0 & 0 & 0 & 0 & 0 & 0 & 4 & 0 \\
\hline & Provannidae & Provanna ios & 0 & 0 & 0 & 9 & 0 & 7 & 0 & 0 & 1 \\
\hline & \multirow[t]{2}{*}{ Conidae } & Phymorhynchus n. sp. & 0 & 0 & 2 & 0 & 0 & 2 & 0 & 0 & 0 \\
\hline & & Phymorhynchus cf. major & 0 & 0 & 0 & 0 & 0 & 2 & 0 & 0 & 0 \\
\hline & Elachisinidae & Laeviphitus sp. & 0 & 0 & 0 & 1 & 0 & 0 & 0 & 0 & 0 \\
\hline & Buccinidae & Eosipho auzendi & 0 & 0 & 0 & 0 & 0 & 6 & 0 & 0 & 4 \\
\hline \multirow[t]{7}{*}{ Polychaetes } & Amphinomidae & Archinome rosacea & 0 & 0 & 15 & 134 & 0 & 389 & 21 & 70 & 25 \\
\hline & Dorvilleidae & Ophryotrocha akessoni & 0 & 0 & 4 & 4 & 0 & 22 & 0 & 50 & 15 \\
\hline & Glyceridae & Glycera n. sp. & 0 & 0 & 0 & 0 & 0 & 0 & 0 & 0 & 1 \\
\hline & \multirow[t]{3}{*}{ Hesionidae } & Hesiospina vestimentifera & 0 & 0 & 0 & 52 & 0 & 332 & 1 & 10 & 0 \\
\hline & & Hesiolyra bergi & 0 & 0 & 0 & 0 & 0 & 0 & 1 & 0 & 0 \\
\hline & & Hesiocaeca cf. hessleri & 0 & 0 & 0 & 26 & 0 & 0 & 0 & 0 & 0 \\
\hline & Nereididae & Nereis sandersi & 0 & 0 & 3 & 10 & 0 & 68 & 26 & 46 & 13 \\
\hline
\end{tabular}




\section{Table 4 Continued}

\begin{tabular}{|c|c|c|c|c|c|c|c|c|c|c|c|}
\hline Taxon & Family & Species & $\begin{array}{l}\text { Sarah's Spring } \\
\left(7^{\circ} 25^{\prime} \mathrm{S}\right)\end{array}$ & $\begin{array}{l}\text { Lucky Eric } \\
\left(13^{\circ} 59^{\prime} \mathrm{S}\right)\end{array}$ & $\begin{array}{l}\text { Oasis BS6 } \\
\left(17^{\circ} 25^{\prime} \mathrm{S}\right)\end{array}$ & $\begin{array}{l}\text { Rehu Marka } \\
\left(17^{\circ} 25^{\prime} \mathrm{S}\right)\end{array}$ & $\begin{array}{l}\text { Susie } \\
\left(17^{\circ} 34^{\prime} \mathrm{S}\right)\end{array}$ & $\begin{array}{l}\text { Animal Farm } \\
\left(18^{\circ} 36^{\prime} \mathrm{S}\right)\end{array}$ & $\begin{array}{l}\text { Grommit (1) } \\
\left(21^{\circ} 33^{\prime} \mathrm{S}\right)\end{array}$ & $\begin{array}{l}\text { Grommit (2) } \\
\left(21^{\circ} 33^{\prime} \mathrm{S}\right)\end{array}$ & $\begin{array}{l}\text { Grommit (3) } \\
\left(21^{\circ} 33^{\prime} \mathrm{S}\right)\end{array}$ \\
\hline \multirow[t]{24}{*}{ (Polychaetes) } & Phyllodocidae & Galapagomystides aristata & 0 & 0 & 0 & 0 & 0 & 2 & 0 & 0 & 0 \\
\hline & \multirow[t]{9}{*}{ Polynoidae } & Branchipolynoe symmytilda & 20 & 20 & 56 & 2 & 23 & 96 & 10 & 5 & 14 \\
\hline & & Branchinotogluma hessleri & 0 & 0 & 0 & 1 & 0 & 0 & 0 & 0 & 0 \\
\hline & & Branchinotogluma sandersi & 0 & 0 & 0 & 0 & 0 & 0 & 0 & 0 & 0 \\
\hline & & Levensteiniella kincaidi & 15 & 0 & 14 & 18 & 0 & 0 & 0 & 10 & 2 \\
\hline & & Levensteiniella plicata & 0 & 0 & 0 & 1 & 0 & 10 & 1 & 0 & 0 \\
\hline & & Lepidonotopodium fimbriatum & 29 & 0 & 0 & 0 & 0 & 0 & 1 & 10 & 3 \\
\hline & & Lepidonotopodium williamsae & 29 & 0 & 4 & 1 & 0 & 0 & 0 & 0 & 0 \\
\hline & & Lepidonotopodium atalantae & 0 & 0 & 1 & 0 & 0 & 0 & 0 & 0 & 0 \\
\hline & & Thermiphione tufari & 0 & 0 & 1 & 2 & 0 & 21 & 3 & 4 & 2 \\
\hline & Serpulidae & Laminatubus alvinus & 0 & 0 & 4 & 0 & 0 & 0 & 0 & 0 & 0 \\
\hline & \multirow[t]{3}{*}{ Siboglinidae } & Oasisia n. sp. & 0 & 17 & 1 & 0 & 0 & 0 & 0 & 0 & 0 \\
\hline & & Riftia pachyptila & 0 & 0 & 1 & 0 & 4 & 0 & 0 & 0 & 0 \\
\hline & & Tevnia jerichonana & 0 & 0 & 0 & 0 & 0 & 0 & 0 & 2 & 0 \\
\hline & Maldanidae & Nicomache n. sp. & 0 & 0 & 8 & 0 & 0 & 0 & 2 & 6 & 1 \\
\hline & Spionidae & Prionospio sp. & 0 & 0 & 1 & 0 & 0 & 0 & 3 & 6 & 0 \\
\hline & Flabelligeridae & Flabelligeridae n. sp. & 0 & 0 & 1 & 0 & 0 & 2 & 0 & 2 & 0 \\
\hline & Sphaerodoridae & Sphaedoropsis n. sp. & 0 & 0 & 0 & 0 & 0 & 40 & 0 & 0 & 0 \\
\hline & \multirow[t]{4}{*}{ Atvinellidae } & Alvinella caudata & 0 & 0 & 0 & 0 & 0 & 0 & 1 & 0 & 0 \\
\hline & & Paralvinella n. sp. & 0 & 0 & 0 & 0 & 0 & 0 & 0 & 28 & 0 \\
\hline & & Paralvinella pandorae & 0 & 0 & 0 & 4 & 1 & 0 & 0 & 0 & 0 \\
\hline & & Paralvinella grasslei & 2 & 0 & 0 & 0 & 0 & 0 & 0 & 0 & 0 \\
\hline & \multirow[t]{2}{*}{ Ampharetidae } & Amphisamytha galapagensis & 1455 & 0 & 18 & 36 & 10 & 229 & 14 & 41 & 78 \\
\hline & & Ampharetidae n. sp. & 0 & 0 & 0 & 0 & 0 & 0 & 1 & 0 & 1 \\
\hline \multirow[t]{2}{*}{ Echinoderms } & Ophiuridae & Spinophiura jolliveti & 0 & 0 & 0 & 0 & 0 & 151 & 0 & 0 & 0 \\
\hline & Ophiocanthidae & Ophiolamina eprae & 0 & 0 & 1 & 1 & 0 & 6 & 0 & 0 & 0 \\
\hline
\end{tabular}


Table 5 Diversity indices for each semi-quantitative sample collected in Bathymodiolus thermophilus mussel beds along the southern East Pacific Rise. N, number of individuals m)2; S, species richness; ES(600), rarefaction index based on a sampling unit size of 600 individuals; J', Pielou's evenness; $\mathrm{H} \Phi$, Shannon-Wiener diversity index; D+, average taxonomic distinctness.

\begin{tabular}{|c|c|c|c|c|c|c|c|}
\hline Vent field & Vent site & $N\left(\right.$ ind. $\mathrm{m}^{-2}$ ) & $S$ & $\mathrm{ES}_{(600)}$ & $J^{\prime}$ & $H^{\prime}\left(\log _{e}\right)$ & $\Delta^{+}$ \\
\hline $7^{\circ} 25^{\prime} \mathrm{S}$ & Sarah's Spring & 3981 & 14 & 12.88 & 0.50 & 1.32 & 75.45 \\
\hline $13^{\circ} 59^{\prime} \mathrm{S}$ & Lucky Eric & 1187 & 11 & 10.76 & 0.53 & 1.27 & 67.20 \\
\hline $17^{\circ} 25^{\prime} \mathrm{S}$ & Oasis - BS6 & 2082 & 26 & 17.48 & 0.23 & 0.75 & 87.02 \\
\hline $17^{\circ} 25^{\prime} \mathrm{S}$ & Rehu Marka & 773 & 25 & 23.78 & 0.75 & 2.40 & 86.01 \\
\hline $17^{\circ} 34^{\prime} \mathrm{S}$ & Susie & 1817 & 13 & 9.81 & 0.20 & 0.53 & 77.09 \\
\hline $18^{\circ} 36^{\prime} \mathrm{S}$ & Animal Farm & 2343 & 24 & 19.91 & 0.73 & 2.32 & 88.84 \\
\hline $21^{\circ} 33^{\prime} \mathrm{S}$ & Grommit (Gr1) & 655 & 25 & 24.22 & 0.40 & 1.29 & 84.6 \\
\hline $21^{\circ} 33^{\prime} \mathrm{S}$ & Grommit (Gr2) & 848 & 27 & 26.58 & 0.68 & 2.26 & 86.28 \\
\hline $21^{\circ} 33^{\prime} \mathrm{S}$ & Grommit (Gr3) & 858 & 24 & 22.39 & 0.56 & 1.79 & 84.2 \\
\hline
\end{tabular}

